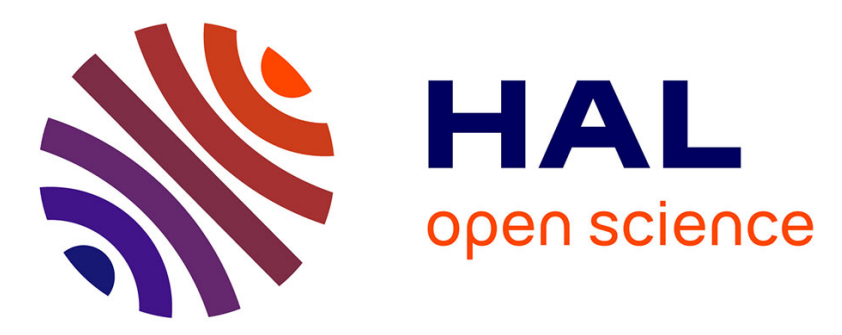

\title{
Microstructures, composition, and seismic properties of the Ontong Java Plateau mantle root
}

\author{
Andrea Tommasi, Akira Ishikawa
}

\section{To cite this version:}

Andrea Tommasi, Akira Ishikawa. Microstructures, composition, and seismic properties of the Ontong Java Plateau mantle root. Geochemistry, Geophysics, Geosystems, 2014, 15 (11), pp.4547-4569. 10.1002/2014GC005452 . hal-01116428

\section{HAL Id: hal-01116428 \\ https://hal.science/hal-01116428}

Submitted on 20 Dec 2021

HAL is a multi-disciplinary open access archive for the deposit and dissemination of scientific research documents, whether they are published or not. The documents may come from teaching and research institutions in France or abroad, or from public or private research centers.
L'archive ouverte pluridisciplinaire HAL, est destinée au dépôt et à la diffusion de documents scientifiques de niveau recherche, publiés ou non, émanant des établissements d'enseignement et de recherche français ou étrangers, des laboratoires publics ou privés. 


\section{Geochemistry, Geophysics, Geosystems}

\section{RESEARCH ARTICLE \\ 10.1002/2014GC005452 \\ Microstructures, composition, and seismic properties of the Ontong Java Plateau mantle root}

\section{Special Section:}

The Lithosphere-asthenosphere System

Key Points:

- Complete sampling of the Ontong Java mantle root from 56 to $120 \mathrm{~km}$ depth

- Calculated velocities inconsistent with low velocities imaged seismologically

- Change in anisotropy may produce an intralithospheric reflector

Supporting Information: - Readme

- Supplementary Material

Correspondence to:

A. Tommasi,

deia@gm.univ-montp2.fr

\section{Citation:}

Tommasi, A., and A. Ishikawa (2014), Microstructures, composition, and seismic properties of the Ontong Java Plateau mantle root, Geochem. Geophys. Geosyst., 15, 4547-4569, doi:10.1002/2014GC005452.

Received 10 JUN 2014 Accepted 29 OCT 2014 Accepted article online 5 NOV 2014 Published online 28 NOV 2014

\section{Introduction}

\author{
Andréa Tommasi ${ }^{1}$ and Akira Ishikawa ${ }^{2}$ \\ ${ }^{1}$ Geosciences Montpellier, CNRS, Université de Montpellier 2, Montpellier, France, ${ }^{2}$ Department of Earth Science and \\ Astronomy, University of Tokyo, Tokyo, Japan
}

\begin{abstract}
To study how an impacting plume modifies the mantle lithosphere, we analyzed the microstructures and crystal preferred orientations (CPO) of 29 peridotites and 37 pyroxenites that sample the mantle root of the Ontong Java Plateau (OJP) from 60 to $120 \mathrm{~km}$ depth. The peridotites show a strong compositional variability, but homogeneous coarse granular to tabular microstructures, except for those equilibrated at the shallowest and deepest depths, which are porphyroclastic. All peridotites have clear olivine CPO, with dominant fiber-[010] patterns. Low intragranular misorientations and straight grain boundaries in olivine suggest that, above $100 \mathrm{~km}$ depth, annealing often followed deformation. Calculated density and $P$ wave velocities of the peridotites decrease weakly with depth. $S$ wave velocities decrease faster, resulting in increasing $\mathrm{Vp} / \mathrm{Vs}$ ratio with depth. Calculated densities and seismic velocity profiles are consistent with those estimated for normal mantle compositions under a cold oceanic geotherm. Enrichment in pyroxenites may further increase seismic velocities. The calculated seismic properties cannot therefore explain the low $S$ waves velocities predicted by Rayleigh wave tomography and ScS data in the mantle beneath the OJP. Calculated $P$ and $S$ waves anisotropy is variable (2-12\%). It is higher on average in the deeper section of the lithosphere. Because olivine has dominantly [010]-fiber CPO patterns, if foliations are horizontal, vertically propagating $S$ waves and Rayleigh waves will sample very weak anisotropy in the OJP mantle lithosphere. Moreover, if the orientation of the lineation changes with depth, the anisotropy-induced contrast in seismic properties might produce an intralithospheric reflector marking the stratification of the OJP mantle root.
\end{abstract}

The Early Cretaceous Ontong Java Plateau (OJP) in the western Pacific is the most voluminous large igneous province on the Earth. It has an area of $\sim 50,000,000 \mathrm{~km}^{2}$ and an average crustal thickness of $33 \mathrm{~km}$ [Richardson et al., 2000]. Most of the plateau is thought to have formed in a single massive volcanism episode at ca. $122 \mathrm{Ma}$ [Mahoney et al., 1993; Tejada et al., 2013], which is generally attributed to a mantle plume. A plume-related genesis is corroborated by the high potential mantle temperature $\left(\sim 1500^{\circ} \mathrm{C}\right)$ estimated from the geochemical characteristics of plateau lavas [Fitton and Godard, 2004; Herzberg, 2004]. Impact of a major thermal plume is, however, inconsistent with both the weak initial uplift (2.5-3.6 km above the surrounding seafloor) documented by submarine eruption of plateau lavas and the weak posteruption subsidence (1.5 $\pm 0.4 \mathrm{~km})$ [Roberge et al., 2005].

Joint analysis of Rayleigh waves seismic tomography and attenuation data suggests an anomalous composition for the upper mantle beneath the OJP. Rayleigh waves seismic tomography imaged slow velocities $(-5 \%)$ up to $300 \mathrm{~km}$ depth beneath most of the plateau [Richardson et al., 2000]. Present-day higher than normal temperatures in the upper mantle beneath Ontong Java are, however, excluded by the low attenuation observed in this region [Gomer and Okal, 2003].

To constrain the tectonothermal evolution of the Ontong Java Plateau mantle root and its seismic properties, we analyzed the microstructures and measured the crystal preferred orientations (CPO) of all major rock-forming minerals from mantle xenoliths carried up by $34 \mathrm{Ma}$ alnöite intrusions (ultramafic lamprophyres enriched in melilite) outcropping on Malaita (Solomon Islands). These xenoliths sample the mantle lithosphere beneath the southwestern part of the OJP (Figure 1a) [Ishikawa et al., 2004; Nixon and Boyd, 1979; Nixon and Neal, 1987]. The analysis of the microstructures and CPO provides information on the deformation conditions, postdeformation thermal evolution (annealing), and reactive melt percolation processes (metasomatism) that affected these rocks. We also calculated the "in situ" densities and seismic properties 


\section{QAGU Geochemistry, Geophysics, Geosystems}
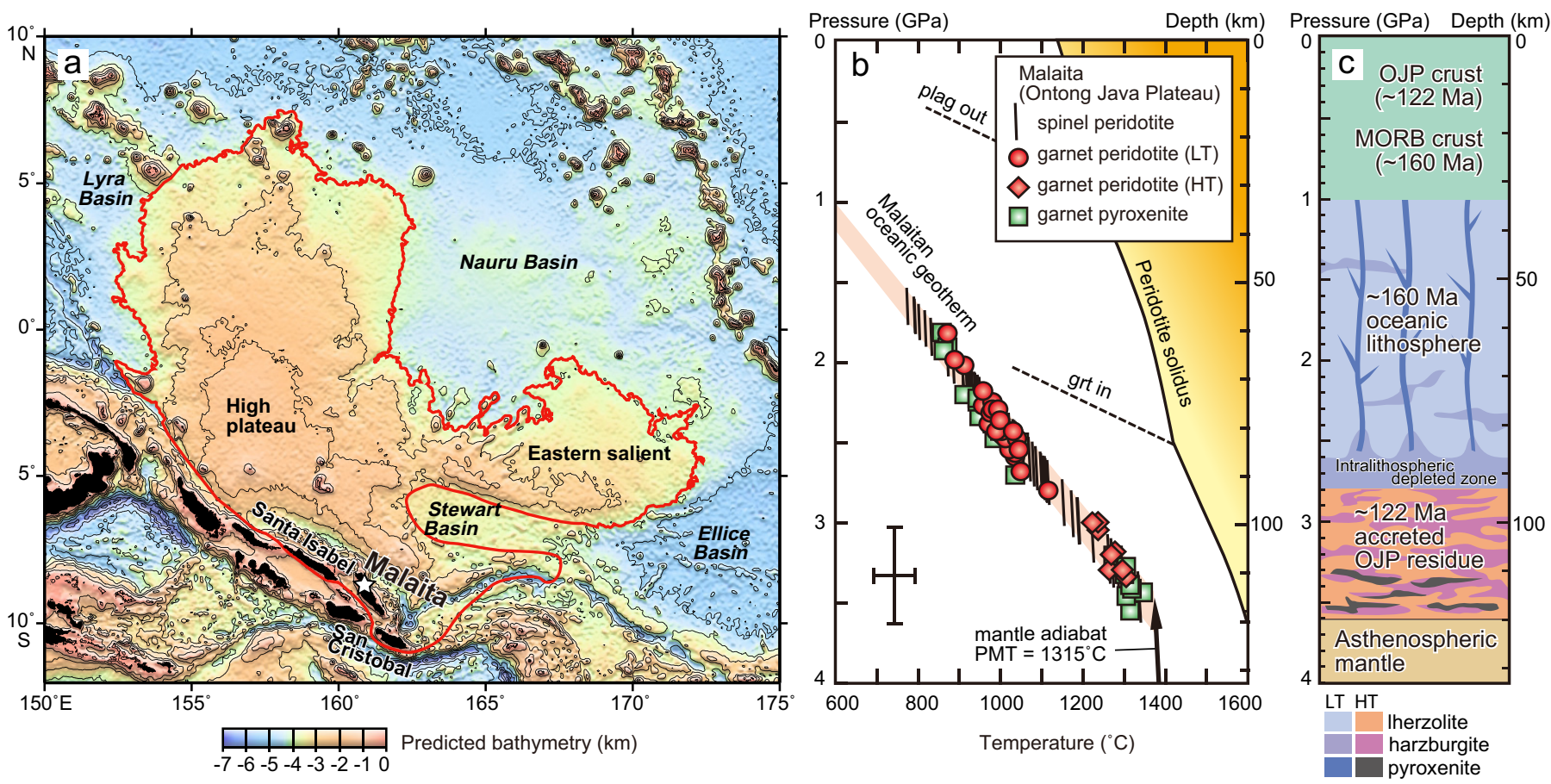

Figure 1. (a) Bathymetric map of the southwestern Pacific Ocean, with the extent of the Ontong Java Plateau (OJP) contoured in red and the location of the Malaita alnöite volcanics, which carried the studied xenoliths, indicated by a star. (b) Geotherm defined by the thermobarometric data for the peridotite and pyroxenite xenoliths [Ishikawa et al., 2004]. (c) Interpretative section illustrating the present-day compositional and age stratification of the OJP lithosphere based on Ishikawa et al. [2004, 2007, 2011].

of the xenoliths based on their CPO, modal composition, and equilibration P-T conditions, as well as on the $\mathrm{P}-\mathrm{T}$ derivatives of the elastic tensors and thermal expansion of the composing minerals [Mainprice, 1990; Mainprice et al., 2000]. Comparison between the calculated densities and seismic properties and existing geophysical data for this region allows discussing the present-day structure of the OJP mantle root.

\section{Prior Results}

The 29 peridotites and 37 pyroxenites selected for this study are part of a larger collection of mantle xenoliths carried up by the alnöite intrusions on Malaita. Their petrology and geochemistry were previously studied by Ishikawa et al. [2004, 2005, 2007, 2011] and the water contents analyzed by Demouchy et al. [2014]. Thermobarometric data indicate that these xenoliths equilibrated over a wide range of P-T conditions (770$1340^{\circ} \mathrm{C}, 1.6-3.6 \mathrm{GPa}$ ) [Ishikawa et al., 2004], which define a cold conductive geotherm that crosscuts the $1300^{\circ} \mathrm{C}$ adiabat at ca. $120 \mathrm{~km}$ depth (Figure $1 \mathrm{~b}$ ). They sample virtually the entire lithospheric mantle beneath the OJP, from 60 to $120 \mathrm{~km}$ depth.

The petrological data and major and trace-element chemistry highlight a compositional stratification of the OJP mantle lithosphere (Figure 1c) [Ishikawa et al., 2004, 2005, 2007, 2011]. The shallow mantle lithosphere ( $<85 \mathrm{~km}$ depth) is composed of spinel Iherzolites and garnet-spinel Iherzolites, with subordinate spinel harzburgites and garnet pyroxenites. Trace-element compositions in the spinel Iherzolites indicate variable metasomatism (Figure 2). Metasomatism is also evidenced by presence of amphibole in garnet-spinel lherzolites (Table 1). The least metasomatized spinel Iherzolites provide an isochron age ( $\mathrm{Sm}-\mathrm{Nd}$ ) of melt depletion ( $\sim 160 \mathrm{Ma}$ ) older than the plateau magmatism ( 120 Ma), marking their origin as part of the Pacific Plate, formed by small degrees of melting at a spreading center ca. $40 \mathrm{Ma}$ before the plateau magmatism [Ishikawa et al., 2005]. This origin is corroborated by the restricted range of ${ }^{187} \mathrm{Os} /{ }^{188} \mathrm{Os}$ ratios $(0.1222-$ 0.1288) displayed by the fertile Iherzolites from this layer [Ishikawa et al., 2011]. The deeper mantle lithosphere (100-120 km depth) is composed of garnet lherzolites, high-temperature spinel harzburgites, and a wide variety of garnet pyroxenites (Figure 1c). The strong compositional variability in this layer was 


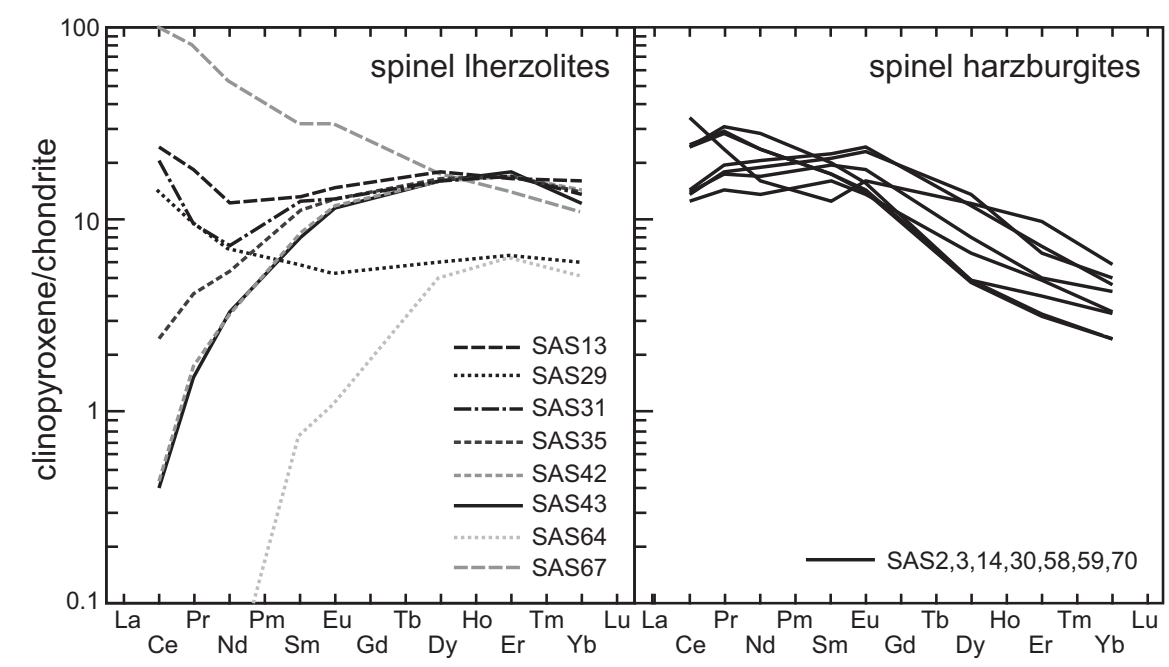

Figure 2. Rare-earth elements patterns for clinopyroxenes from spinel Iherzolites and spinel harzburgites (data from Ishikawa et al. [2004]). Chondrite normalizing values are from Anders and Grevesse [1989].

interpreted by Ishikawa et al. [2004, 2007] as resulting from variable degrees of partial melting of a mixed peridotite-pyroxenite source in the mantle plume and associated reactive melt percolation.

These two compositionally distinct layers are separated an intralithospheric depleted zone, $\sim 15 \mathrm{~km}$ thick (85-100 km depth), which is barren of garnet-bearing xenoliths (Figure 1c). This interval is dominated by refractory harzburgites containing olivine with high forsterite contents ( $M g \#=91-92$, Table 1) [lshikawa et al., 2004]. The high potential temperatures $\left(>1600^{\circ} \mathrm{C}\right)$ required for producing refractory harzburgites in a high-pressure environment $(\geq 2.5 \mathrm{GPa})$ [Herzberg, 2004] favor a hot plume hypothesis for the plateau generation. The cold geotherm defined by the xenoliths' thermobarometry (Figure 1b) implies, however, cooling between the plateau formation (120 Ma) and the xenoliths extraction (34 Ma). Some of these refractory harzburgites show osmium depletion, $\mathrm{Ti}$ enrichment in clinopyroxene (up to $1.1 \mathrm{wt} \% \mathrm{TiO}_{2}$ ), and variable amount of amphiboles, which suggest interaction with melts [Ishikawa et al., 2004, 2011]. Metasomatism by water-rich evolved melts or fluids is also inferred from the high hydrogen concentration in olivine ( $\sim 32$ ppm wt $\mathrm{H}_{2} \mathrm{O}$ ) measured in refractory spinel harzburgites equilibrated at depths of $85 \mathrm{~km}$ [Demouchy et al., 2014]. In contrast, the Iherzolites show a weak increase in concentration of hydrogen in olivine with depth from 2 to 20 ppm wt $\mathrm{H}_{2} \mathrm{O}$ [Demouchy et al., 2014].

Based on these data, the present-day OJP mantle lithosphere was inferred to have a two-layer structure (Figure 1c), where a "normal" oceanic mantle lithosphere partially metasomatized by plume-related melts is underlain by a $35 \mathrm{~km}$ thick layer extensively modified by the plume activity, with trapped melts frozen as pyroxenitic layers or lenses [Ishikawa et al., 2004, 2007, 2011]. Such a layered structure is consistent with predictions of numerical models simulating the interaction between a plume and a fast-moving plate [Thoraval et al., 2006; Bianco et al., 2008; Agrusta et al., 2013]. In these models, small-scale convection within the low viscosity layer formed by plume material spreading at the base of the lithosphere produces limited bottom-up thinning of the plate (up to $20 \mathrm{~km}$ of uplift of the $1300^{\circ} \mathrm{C}$ isotherm). Limited conductive heating and percolation of melts affect the remaining lithosphere. Cooling of the system with increasing distance from the plume impact point results in underplating of the thinned oceanic lithosphere by a mixture of plume material submitted to variable degrees of partial melting and material recycled from the base of the lithosphere by the small-scale convection.

\section{Methods}

\subsection{Sampling}

The sample selection aimed to probe, with samples that preserve the original mantle mineralogy in at least $70 \%$ of the volume, the entire depth interval (from 60 to $120 \mathrm{~km}$ depth) and the variety of lithological facies present in this xenolith suite. The peridotites and pyroxenites modal compositions, olivine forsterite content 
Table 1. Composition, Equilibration Conditions, Microstructure, Strength (J-Index), and Symmetry (BA-Index, See Section 3 for Explanation) of the Olivine Crystal Preferred Orientations, and Seismic Properties (Mean Velocities in km/s and Anisotropies in \% for $P$ and $S$ waves) of All Studied Peridotite Xenoliths ${ }^{a}$

\begin{tabular}{|c|c|c|c|c|c|c|c|c|c|c|c|c|c|c|c|c|c|c|c|c|c|}
\hline Sample & $\begin{array}{l}\text { Rock } \\
\text { Type }\end{array}$ & Ol & Opx & Cpx & Sp & Grt & Amp & Ol Mg\# & $\begin{array}{l}\text { Depth } \\
(\mathrm{km})\end{array}$ & $\begin{array}{c}\mathrm{P} \\
(\mathrm{GPa})\end{array}$ & $\begin{array}{c}\mathrm{T} \\
\left({ }^{\circ} \mathrm{C}\right)\end{array}$ & Microstructure & $\begin{array}{c}\text { J- } \\
\text { Index }\end{array}$ & $\begin{array}{l}\text { BA- } \\
\text { Index }\end{array}$ & $\begin{array}{l}\text { Density } \\
\left(\mathrm{kg} / \mathrm{m}^{3}\right)\end{array}$ & $\begin{array}{c}\text { Vp } \\
\text { Mean }\end{array}$ & $\begin{array}{c}\mathrm{Vp} \\
\text { Amax }\end{array}$ & $\begin{array}{c}\text { Vs } \\
\text { Mean }\end{array}$ & $\begin{array}{l}\text { Vs1 } \\
\text { Mean }\end{array}$ & $\begin{array}{l}\text { Vs2 } \\
\text { Mean }\end{array}$ & $\begin{array}{c}\text { Vs } \\
\text { APolmax }\end{array}$ \\
\hline SAS64 & $S L$ & 56 & 37 & 6 & 1 & & & 90.4 & 56.9 & 1.73 & 791 & Porphyroclastic & 3.2 & 0.31 & 3290 & 8.02 & 6.20 & 4.62 & 4.69 & 4.54 & 5.33 \\
\hline SAS31 & SL & 46 & 36 & 15 & 3 & & & 89.8 & 70.3 & 2.14 & 918 & $\begin{array}{l}\text { Annealed coarse } \\
\text { granular }\end{array}$ & 5.6 & 0.29 & 3275 & 7.99 & 3.99 & 4.59 & 4.64 & 4.55 & 3.34 \\
\hline SAS35 & SL & 62 & 26 & 9 & 2 & & & 89.8 & 71.9 & 2.18 & 933 & $\begin{array}{l}\text { Coarse granular/ rare } \\
\text { SG in olivine }\end{array}$ & 8.0 & 0.54 & 3292 & 7.99 & 3.99 & 4.59 & 4.64 & 4.55 & 3.34 \\
\hline SAS42 & SL & 57 & 31 & 11 & 1 & & & 89.5 & 72.5 & 2.20 & 939 & $\begin{array}{l}\text { Coarse } \\
\text { granular/ closely } \\
\text { spaced SG in ol }\end{array}$ & 6.1 & 0.54 & 3285 & 7.98 & 2.08 & 4.59 & 4.61 & 4.56 & 2.88 \\
\hline SAS29 & SL & 68 & 26 & 5 & 1 & & & 91.1 & 73.3 & 2.23 & 947 & $\begin{array}{l}\text { Coarse } \\
\text { granular/ ol SPO, } \\
\text { rare SG in ol }\end{array}$ & 8.0 & 0.17 & 3296 & 8.04 & 9.23 & 4.58 & 4.69 & 4.47 & 8.02 \\
\hline SAS43 & SL & 52 & 28 & 16 & 3 & & & 89.7 & 77.7 & 2.36 & 988 & $\begin{array}{l}\text { Coarse } \\
\text { granular/ closely } \\
\text { spaced SG in ol }\end{array}$ & 8.5 & 0.47 & 3280 & 8.03 & 6.80 & 4.57 & 4.64 & 4.5 & 5.49 \\
\hline SAS13 & SL & 61 & 25 & 10 & 3 & & & 89.8 & 78.1 & 2.37 & 992 & $\begin{array}{l}\text { Annealed coarse } \\
\text { granular to tabular }\end{array}$ & 5.4 & 0.40 & 3290 & 7.99 & 5.17 & 4.56 & 4.63 & 4.49 & 5.41 \\
\hline SAS67 & SL & 57 & 24 & 5 & 0 & & 15 & 89.5 & 79.4 & 2.41 & 1004 & $\begin{array}{l}\text { Coarse granular/ SG } \\
\text { in ol/ poikilitic amph }\end{array}$ & 8.8 & 0.24 & 3266 & 7.90 & 5.94 & 4.55 & 4.60 & 4.50 & 5.25 \\
\hline SAS53 & GSL & 28 & 27 & 26 & $\operatorname{tr}$ & 18 & & 88.4 & 65.4 & 1.78 & 872 & $\begin{array}{l}\text { Annealed coarse } \\
\text { granular }\end{array}$ & 4.0 & 0.56 & 3273 & 8.16 & 2.67 & 4.58 & 4.72 & 4.65 & 2.42 \\
\hline SAS12 & GSL & 48 & 20 & 17 & $\operatorname{tr}$ & 15 & $\operatorname{tr}$ & 88.3 & 67.2 & 1.94 & 889 & Annealed tabular & 3.8 & 0.32 & 3323 & 8.12 & 3.99 & 4.64 & 4.68 & 4.61 & 3.49 \\
\hline SAS44 & GSL & 52 & 23 & 11 & $\operatorname{tr}$ & 10 & 4 & 89.5 & 78.8 & 2.38 & 999 & $\begin{array}{l}\text { Annealed coarse } \\
\text { granular to tabular }\end{array}$ & 5.6 & 0.24 & 3300 & 8.06 & 5.80 & 4.61 & 4.65 & 4.57 & 4.76 \\
\hline SAS57 & GSL & 66 & 20 & 11 & $\operatorname{tr}$ & 3 & & 90.4 & 82.3 & 2.44 & 1032 & $\begin{array}{l}\text { Annealed coarse } \\
\text { granular }\end{array}$ & 4.8 & 0.25 & 3292 & 8.01 & 6.21 & 4.56 & 4.63 & 4.50 & 4.64 \\
\hline SAG31 & GSL & 55 & 21 & 11 & $\operatorname{tr}$ & 13 & 1 & 89.5 & 83.7 & 2.57 & 1045 & Annealed tabular & 4.4 & 0.13 & 3318 & 8.13 & 5.29 & 4.62 & 4.68 & 4.56 & 4.55 \\
\hline SAS14 & $\mathrm{SH}$ & 67 & 30 & 2 & & & & 91.9 & 76.0 & 2.31 & 972 & $\begin{array}{l}\text { Coarse granular/ SG } \\
\text { in ol/poikilitic } \\
\text { opx + amph }\end{array}$ & 7.3 & 0.19 & 3293 & 8,00 & 8.16 & 4.58 & 4.67 & 4.49 & 7.57 \\
\hline SAS3 & $\mathrm{SH}$ & 75 & 20 & 4 & 2 & & & 91.7 & 80.1 & 2.43 & 1011 & $\begin{array}{l}\text { Annealed coarse } \\
\text { granular }\end{array}$ & 6.2 & 0.33 & 3302 & 8.04 & 8.76 & 4.55 & 4.62 & 4.47 & 6.49 \\
\hline SAS58 & $\mathrm{SH}$ & 71 & 23 & 1 & 2 & & 3 & 89.8 & 81.3 & 2.47 & 1022 & Coarse granular & 9.7 & 0.38 & 3295 & 8.01 & 9.02 & 4.55 & 4.65 & 4.45 & 7.10 \\
\hline SAS30 & $\mathrm{SH}$ & 81 & 18 & 1 & & & & 91.9 & 82.9 & 2.52 & 1038 & $\begin{array}{l}\text { Annealed coarse } \\
\text { granular to } \\
\text { tabular/ rare } \\
\text { SG in ol }\end{array}$ & 5.2 & 0.46 & 3303 & 8.02 & 7.10 & 4.55 & 4.65 & 4.46 & 6.24 \\
\hline SAS20 & $\mathrm{SH}$ & 72 & 23 & & 2 & & 3 & 92.0 & 83.8 & 2.55 & 1046 & $\begin{array}{l}\text { Annealed coarse } \\
\text { granular to } \\
\text { tabular }\end{array}$ & 9.6 & 0.18 & 3295 & 8,00 & 10.19 & 4.54 & 4.65 & 4.44 & 9.08 \\
\hline SAS2 & $\mathrm{SH}$ & 63 & 35 & & & & 2 & 91.5 & 86.3 & 2.62 & 1070 & $\begin{array}{l}\text { Annealed coarse } \\
\text { granular }\end{array}$ & 6.6 & 0.22 & 3282 & 7.96 & 7.31 & 4.56 & 4.65 & 4.47 & 5.74 \\
\hline SAS59 & $\mathrm{SH}$ & 77 & 21 & & 1 & & 1 & 91.4 & 89.5 & 2.72 & 1100 & $\begin{array}{l}\text { Coarse granular } \\
\text { to tabular }\end{array}$ & 4.1 & 0.93 & 3289 & 7.97 & 9.31 & 4.50 & 4.59 & 4.40 & 6.35 \\
\hline SAS70 & $\mathrm{SH}$ & 67 & 30 & & 1 & & 2 & 91.8 & 91.2 & 2.77 & 1116 & $\begin{array}{l}\text { Annealed coarse } \\
\text { granular }\end{array}$ & 5.1 & 0.65 & 3286 & 8.01 & 8.10 & 4.56 & 4.65 & 4.46 & 5.91 \\
\hline SAS82 & $\mathrm{GH}$ & 58 & 32 & & & 1 & 9 & 86.8 & 91.2 & 2.77 & 1117 & Coarse granular & 11.4 & 0.31 & 3285 & 7.94 & 9.98 & 4.52 & 4.62 & 4.42 & 8.11 \\
\hline SAG1 & $\mathrm{GL}$ & 63 & 16 & 12 & & 9 & & 90.2 & 103.0 & 3.01 & 1235 & $\begin{array}{l}\text { Coarse granular, } \\
\text { deformed/ ol SPO }\end{array}$ & 6.3 & 0.19 & 3308 & 8.04 & 9.21 & 4.53 & 4.63 & 4.43 & 6.63 \\
\hline SAG30 & $\mathrm{GL}$ & 47 & 18 & 22 & & 13 & & 90.1 & 106.8 & 3.30 & 1264 & $\begin{array}{l}\text { Coarse granular, } \\
\text { deformed/ ol SPO }\end{array}$ & 7.3 & 0.22 & 3303 & 8.09 & 6.75 & 4.57 & 4.65 & 4.48 & 5.55 \\
\hline SAG21 & $\mathrm{GL}$ & 54 & 21 & 14 & & 11 & & 87.0 & 110.3 & 3.31 & 1297 & $\begin{array}{l}\text { Coarse granular, } \\
\text { partially } \\
\text { recrystallized }\end{array}$ & 6.4 & 0.24 & 3301 & 8.05 & 5.42 & 4.53 & 4.59 & 4.46 & 5.5 \\
\hline SAG27 & $\mathrm{GL}$ & 58 & 31 & 8 & & 3 & & 87.6 & 110.9 & 3.36 & 1303 & $\begin{array}{l}\text { Coarse granular, } \\
\text { partially } \\
\text { recrystallized }\end{array}$ & 3.9 & 0.40 & 3278 & 7.95 & 5.98 & 4.48 & 4.56 & 4.41 & 5.74 \\
\hline SAS21 & HTSH & 58 & 42 & 0 & $\operatorname{tr}$ & & & 92.3 & 99.0 & 3.01 & 1190 & Coarse granular & 7.1 & 0.38 & 3274 & 7.96 & 7.38 & 4.56 & 4.66 & 4.46 & 7.11 \\
\hline SAS69 & HTSH & 74 & 26 & 0 & $\operatorname{tr}$ & & & 91.4 & 106.7 & 3.24 & 1263 & $\begin{array}{l}\text { Coarse granular, } \\
\text { slightly } \\
\text { deformed/ ol SPO }\end{array}$ & 6.4 & 0.55 & 3291 & 7.97 & 10.64 & 4.50 & 4.62 & 4.38 & 8.18 \\
\hline SAS1 & HTSH & 76 & 22 & 2 & $\operatorname{tr}$ & & & 91.6 & 114.6 & 3.48 & 1338 & $\begin{array}{l}\text { Coarse granular/ ol } \\
\text { SPO, partially } \\
\text { recrystallized }\end{array}$ & 8.7 & 0.41 & 3291 & 7.95 & 11.43 & 4.47 & 4.60 & 4.33 & 9.00 \\
\hline
\end{tabular}

${ }^{a} \mathrm{SL}=$ spinel Iherzolite; GSL = garnet spinel Iherzolite; $\mathrm{SH}=$ spinel harzburgite; $\mathrm{GL}=$ garnet lherzolite; HTSH = high-temperature spinel harzburgite. OI = olivine; $\mathrm{Opx}=$ orthopyroxene; $\mathrm{Cpx}=$ clinopyroxene; $\mathrm{Sp}=$ spinel; $\mathrm{Grt}=$ garnet; $\mathrm{Amp}=$ amphibole. SPO = shape-preferred orientation; SG = subgrains. 


\begin{tabular}{|c|c|c|c|c|c|c|c|c|c|c|c|c|c|c|}
\hline Sample & Rock Type & Depth (km) & $\mathrm{P}(\mathrm{GPa})$ & $\mathrm{T}\left({ }^{\circ} \mathrm{C}\right)$ & Ol & Opx & Cpx & Grt & Sp & Amp & Qtz & Density $\left(\mathrm{kg} / \mathrm{m}^{3}\right)$ & $\mathrm{Vp}(\mathrm{km} / \mathrm{s})$ & Vs $(\mathrm{km} / \mathrm{s})$ \\
\hline SAE122 & GW & 63.8 & 1.82 & 857 & & 36 & 39 & 25 & & & & 3300 & 8.21 & 4.74 \\
\hline SAE134 & GW & 69.6 & 2.21 & 911 & & 10 & 72 & 18 & & & & 3283 & 8.19 & 4.67 \\
\hline SAE106 & GW & 73.2 & 2.26 & 945 & & 21 & 66 & 13 & & & & 3265 & 8.12 & 4.65 \\
\hline SAE103 & GW & 73.6 & 2.27 & 950 & & 21 & 62 & 17 & & & & 3265 & 8.16 & 4.67 \\
\hline SAE117 & GW & 77.0 & 2.4 & 982 & & 11 & 66 & 22 & & 2 & & 3288 & 8.21 & 4.68 \\
\hline SAE138 & GW & 77.5 & 2.48 & 986 & 1 & 21 & 43 & 35 & & & & 3328 & 8.35 & 4.76 \\
\hline SAE111 & GW & 78.8 & 2.45 & 999 & & 11 & 65 & 24 & & & & 3293 & 8.24 & 4.69 \\
\hline SAE105 & GW & 82.5 & 2.7 & 1034 & & & 73 & 27 & & & & 3300 & 8.29 & 4.69 \\
\hline SAE148 & OGC & 69.6 & 2.12 & 912 & 35 & & 14 & 51 & & & & 3415 & 8.51 & 4.81 \\
\hline SAE104 & SGC & 77.9 & 2.37 & 990 & & & 60 & 40 & & & & 3343 & 8.4 & 4.76 \\
\hline SAE109 & SGC & 79.4 & 2.42 & 1005 & 4 & & 32 & 62 & 2 & & & 3448 & 8.6 & 4.86 \\
\hline SAE130 & SGC & 81.6 & 2.48 & 1025 & & & 51 & 44 & 5 & & & 3444 & 8.44 & 4.76 \\
\hline SAE124 & SGC & 82.8 & 2.52 & 1037 & & & 65 & 35 & & & & 3326 & 8.35 & 4.73 \\
\hline SAE101 & SGC & 83.8 & 2.51 & 1046 & 13 & & 32 & 56 & & & & 3401 & 8.53 & 4.82 \\
\hline SAE140 & SGC & 85.6 & 2.6 & 1063 & & & 43 & 56 & 2 & & & 3422 & 8.54 & 4.82 \\
\hline SAE108 & SGC & 86.1 & 2.62 & 1068 & & & 45 & 43 & 11 & & & 3561 & 8.45 & 4.75 \\
\hline SAE112 & SGC & 86.1 & 2.62 & 1068 & & & 74 & 26 & & & & 3294 & 8.26 & 4.68 \\
\hline SAE110 & SGC & 87.1 & 2.65 & 1077 & & & 41 & 57 & 3 & & & 3440 & 8.55 & 4.82 \\
\hline SAE118 & SGC & 87.6 & 2.66 & 1082 & & & 50 & 43 & 2 & 5 & & 3377 & 8.41 & 4.76 \\
\hline SAE115 & SGC & 104.7 & 3.18 & 1244 & & & 58 & 34 & 5 & 4 & & 3407 & 8.32 & 4.69 \\
\hline SAG19 & GO & 107.2 & 3.05 & 1268 & & 88 & & 11 & & & & 3213 & 7.94 & 4.66 \\
\hline SAE137 & GO & 107.8 & 3.28 & 1273 & & & 56 & 38 & 6 & & & 3428 & 8.38 & 4.70 \\
\hline SAE114 & GO & 108.8 & 3.27 & 1283 & & 83 & & 17 & & & & 3249 & 8.02 & 4.68 \\
\hline SAE151 & GO & 109.2 & 3.26 & 1287 & & 85 & & 15 & & & & 3243 & 8.00 & 4.67 \\
\hline SAE126 & GO & 110.5 & 3.34 & 1299 & & 44 & 5 & 52 & & & & 3361 & 8.41 & 4.82 \\
\hline SAE137 & GO & 110.9 & 3.28 & 1303 & 2 & 85 & & 13 & & & & 3236 & 7.97 & 4.66 \\
\hline SAX37 & GO & 111.2 & 3.47 & 1306 & 4 & 61 & 4 & 31 & & & & 3301 & 8.20 & 4.73 \\
\hline SAE139 & GO & 112.0 & 3.4 & 1314 & & 70 & & 30 & & & & 3274 & 8.17 & 4.73 \\
\hline SAE136 & GO & 112.8 & 3.43 & 1321 & 7 & 73 & 3 & 17 & & & & 3257 & 8.03 & 4.66 \\
\hline SAE135 & GO & 115.2 & 3.44 & 1344 & & 67 & 9 & 24 & & & & 3271 & 8.11 & 4.69 \\
\hline SAE141 & GC & 112.3 & 3.41 & 1316 & & 10 & 84 & 6 & & & & 3221 & 8.04 & 4.54 \\
\hline SAE113 & GC & 113.3 & 3.44 & 1326 & & & 55 & 45 & & & & 3343 & 8.42 & 4.74 \\
\hline SAE154 & GC & 114.0 & 3.56 & 1333 & & & 65 & 35 & & & & 3313 & 8.34 & 4.69 \\
\hline SAE116 & GC & 116.6 & 3.54 & 1357 & & & 75 & 21 & & & 4 & 3142 & 8.21 & 4.61 \\
\hline SAE152 & GC & 117.9 & 3.58 & 1370 & & & 83 & 17 & & & & 3254 & 8.17 & 4.59 \\
\hline SAE107 & GC & 119.4 & 3.63 & 1383 & & & 64 & 36 & & & & 3314 & 8.34 & 4.69 \\
\hline SAE120 & GC & 122.6 & 3.73 & 1414 & & & 54 & 46 & & & & 3342 & 8.42 & 4.73 \\
\hline
\end{tabular}

${ }^{\mathrm{a}} \mathrm{GW}=$ garnet websterite; OGC = olivine-garnet clinopyroxenite; SGC = spinel-garnet clinopyroxenite; GO = garnet orthopyroxenite; GC = garnet clinopyroxenite. Note that temperature estimates for orthopyroxene-free pyroxenites (that is, most SGC and GC pyroxenites) may be slightly overestimated relative to those for other pyroxenites, which were calculated based on two-pyroxene thermometers (details in Ishikawa et al. [2004]).

(Mg\#), and equilibration conditions are summarized in Tables 1 and 2, respectively. The variation of modal composition with depth is also presented graphically in supporting information Figure S1. Mineral compositions of three newly analyzed samples are presented in supporting information Table S1.

Modal compositions were obtained by processing of automatic X-ray concentration maps covering an entire thin section with the following assumptions: (i) late veins filled with carbonate were not included in the calculation, (ii) carbonates and serpentines replacing olivine were calculated as olivine, and (iii) kelyphitized margins of garnet were calculated as garnet. Electron Back Scattered Diffraction mapping (described below) on another thin section of the same sample corroborates these data, indicating an uncertainty of $\pm 1 \%$.

The pressure and temperature of equilibration of the studied xenoliths were determined by Ishikawa et al. [2004]. As these data are essential for the present study, we recall here the methods used and the associated uncertainty. Equilibration pressure and temperature of garnet-bearing peridotites and pyroxenites were determined using the Al-in-orthopyroxene geobarometer and the two-pyroxene geothermometer of Brey and Köhler [1990], which yield typical errors of $\pm 3 \mathrm{kbar}(0.3 \mathrm{GPa})$ and $\pm 20^{\circ} \mathrm{C}$, respectively. Nimis and Grütter [2010] recently questioned the accuracy of this thermometer-barometer combination and suggested that more reliable pressure and temperature estimates are provided by combining the Taylor [1998] twopyroxene geothermometer and the Al-in-orthopyroxene geobarometer of Nickel and Green [1985]. In the present case, recalculation of equilibration pressure and temperatures using these methods resulted in a systematic decrease of temperature of $\mathrm{ca} .50^{\circ} \mathrm{C}$ for all xenoliths with minor change on the pressure 
estimates (average discrepancy is $+1 \mathrm{kbar}$ ). The inferred lithological variation with depth is therefore robust, but typical errors on temperature should be increased to $\pm 50^{\circ} \mathrm{C}$. The equilibration temperatures of garnetfree peridotites were determined using the two-pyroxene geothermometer from Brey and Köhler [1990]. The equilibration pressure has been inferred from the geotherm defined by a linear least squares regression of the pressure-temperature data of garnet-bearing xenoliths $\left[\mathrm{T}\left({ }^{\circ} \mathrm{C}\right)=311.67 \mathrm{P}(\mathrm{kbar})+252.29\right.$, Figure $\left.1 \mathrm{~b}\right]$. Analysis of the equilibration conditions highlights that the pyroxenites are mainly derived from two depth intervals: $70-90 \mathrm{~km}$ depth and 105-120 km depth (Figure 1b).

\subsection{Crystallographic Preferred Orientations (CPO)}

CPO of olivine, orthopyroxene, clinopyroxene, garnet, and amphibole were obtained by indexing Electron Back Scattered Diffraction (EBSD) Kikuchi patterns generated in a JEOL JSM 5600 scanning electron microscope at Geosciences Montpellier (Université de Montpellier 2, France) using the CHANNEL + software (Oxford-HKL Technology). An acceleration voltage of $17 \mathrm{kV}$ and a working distance of $23 \mathrm{~mm}$ were used. Orientation maps covering $90-100 \%$ of the thin section were acquired in automatic acquisition mode with a step size of 25-50 $\mu \mathrm{m}$, depending on grain size (step size was always at least 5 times smaller than the average grain size). Indexing rates in most samples were between 75 and $90 \%$. Reaction products with the alnöite could not be indexed, resulting in lower indexation rates (50-60\%) in a few samples. This reaction only affected the boundary of the crystals and no evidence for a directional dependence was observed. The lower indexing rates in the partially reacted samples do not result therefore in bias in the CPO determination. Standard postacquisition data treatment for olivine-rich rocks [cf. Tommasi et al., 2008] allowed increasing the proportion of indexed points. When a shape-preferred orientation (SPO) of olivine is present, the $\mathrm{CPO}$ is displayed in the sample structural reference frame on equal area lower hemisphere stereoplots. For those samples where olivine does not have a SPO, the CPO was arbitrarily rotated to have the maximum concentrations of [100] and [010] axes of olivine parallel to lineation and foliation of the specimens with an olivine SPO to allow for easy comparison between samples.

The olivine CPO strength was determined using the J-index, which is the volume-averaged integral of the squared orientation densities [Bunge, 1982]. It ranges from 1 for a random distribution to infinity for an olivine single crystal; in practice it has a maximum around 250 owing to truncation at expansion 22 of the spherical harmonic series [Ben Ismail and Mainprice, 1998]. The J-index was calculated using the MTEX toolbox in Matlab (http://mtex.googlecode.com) [Bachmann et al., 2010; Hielscher and Schaeben, 2008; Mainprice et al., 2011] with orientation distribution functions (ODF) calculated using a "de la Vallée Poussin" kernel with a half width of $10^{\circ}$. This calculation was performed using one orientation datum per pixel, because this allows relating the CPO strength to the variations in grain size. Large crystals contribute more to the Jindex, as they do for the anisotropy of physical properties.

To characterize the symmetry of the olivine CPO the BA-index [Mainprice et al., 2014] was used. It is calculated as

$$
\text { BA-index }=\frac{1}{2}\left(2-\left(\frac{P_{010}}{G_{010}+P_{010}}\right)-\left(\frac{G_{100}}{G_{100}+P_{100}}\right)\right)
$$

where $P$ and $G$ are the Point and Girdle fabric indices [Vollmer, 1990] for the [100] and [010] crystallographic axes. These indices were also calculated using the MTEX software. For each axis, the orientation tensor and its three eigenvalues $\lambda_{1}, \lambda_{2}, \lambda_{3}$ (where $\lambda_{1} \geq \lambda_{2} \geq \lambda_{3}$ and $\lambda_{1}+\lambda_{2}+\lambda_{3}=1$ ) are used to determine

$$
P=\lambda_{1}-\lambda_{2} \text { and } G=2\left(\lambda_{2}-\lambda_{3}\right)
$$

For a perfect [010]-fiber CPO, the $P$ and $G$ values for [010] and [100] are 1, 0 and 0, 1, respectively, and the BA-index is 0 . In the other end-member case, a perfect [100]-fiber CPO, the $P$ and $G$ values for [100] and [010] are 1, 0 and 0, 1, respectively, and the BA-index is 1.

\subsection{Grain Size Distributions, Shape-Preferred Orientations, and Intracrystalline Misorientations} Grain sizes and shape-preferred orientations were determined from the EBSD maps using the automatic grain detection routine in the MTEX toolbox. This routine is based on a Voronoi decomposition and fills missing measurements in a consistent way, which is both phase and rotational invariant 
[Bachmann et al., 2011]. Examples of this analysis for samples with different microstructures are presented in supporting information Figure S2.

For characterizing the annealing (static recrystallization) degree of the samples, we analyzed the intracrystalline orientation gradients. For each grain, we measured the mean misorientation of each point from the average orientation of the grain as well as the first-order and second-order kernel average misorientations (KAM1 and KAM2), which are the average misorientation of each point to all of its 4 first-order (immediate) and 12 second-order neighbors, respectively. The decrease in the mean KAM2 values (averaged over all olivine grains in the sample) is used here as a proxy for the annealing degree, based on the observation that the first consequence of annealing is the reduction of the free dislocations density and, hence, of the intracrystalline misorientations.

\subsection{Seismic Properties}

Seismic properties of the peridotites were calculated based on the olivine, orthopyroxene, clinopyroxene, and garnet CPOs and on modal compositions [Mainprice, 1990]. Pyroxenites seismic properties were calculated using their modal compositions, but considering that all phases have a random crystal preferred orientation. For olivine with Mg\# between 89.5 and 90.5, the elastic tensor for San Carlos olivine, which has an Mg\# = 90 [Abramson et al., 1997], was used. For more Fe or Mg-rich compositions, we used olivine elastic tensors recalculated by interpolation from the single crystal elastic constant tensors for fayalite, forsterite, and olivine with Mg\# of 90, 91, and 93 [Abramson et al., 1997; Isaak et al., 1989; Kumazawa and Anderson, 1969; Suzuki et al., 1983; Webb, 1989]. For orthopyroxene, clinopyroxene, garnet, chromite, and coesite, we used the single crystal elastic tensors of Chai et al. [1997a, 1997b], Collins and Brown [1998], Hearmon [1984], and Weidner and Carleton [1977]. As the single crystal elastic tensor for pargasite is not available, data for glaucophane [Mookherjee and Bezacier, 2012] was used.

To account for the effect of pressure and temperature on the seismic properties, elastic tensors and density of olivine, pyroxenes, garnet, chromite, and amphibole were recalculated for the equilibration pressure and temperature of each sample using the AnisPT10 software by D. Mainprice, based on published pressure and temperature derivatives of the elastic constants [Abramson et al., 1997; Bezacier, 2012; Chai et al., 1997a, 1997b; Collins and Brown, 1998; Mookherjee and Bezacier, 2012; Reichmann and Jacobsen, 2004]. Voigt-ReussHill averaging was applied in all calculations. Seismic properties of all samples were then calculated using the Christoffel equation. They are summarized in Tables 1 and 2. The three-dimensional distribution of seismic velocities and birefringence of $S$ waves relatively to the samples' structural reference frame is displayed on lower hemisphere stereograms.

For comparison, the variation of the density and isotropic $P$ and $S$ wave velocities along the geotherm defined from the xenoliths' thermobarometric data (Figure 1c) for typical fertile and refractory mantle compositions, as well as for a pyrolitic mantle, were calculated using the same method. For fertile compositions, the spinel-garnet transition depth depends on the $\mathrm{Cr}$ content of spinel [Klemme, 2004]. For the pyrolitic composition, we present therefore two cases: a pyrolite containing $\mathrm{Cr}$-poor spinels (labeled pyrolite) and another containing $\mathrm{Cr}$-rich spinels (labeled $\mathrm{Cr}$-pyrolite). The variation in modal composition with depth for these four models is presented in supporting information Figure S1.

Uncertainty in the calculated seismic velocities may stem from (1) the averaging method, (2) the $\pm 1 \%$ uncertainty in the determination of the modal composition, (3) the $\pm 50^{\circ} \mathrm{C}$ and $\pm 0.2 \mathrm{GPa}$ uncertainty in the determination of the equilibration temperatures, and (4) uncertainties in temperature and pressure derivatives of the elastic constants. Points (2) and (3) induce uncertainties lower than $\pm 1 \%$ in calculated seismic velocities. Point (4) cannot be constrained by the existing experimental data. Seismic anisotropy estimates are less sensitive to the above uncertainties [Mainprice et al., 2000].

\section{Microstructures}

\subsection{Upper (<100 km Depth) OJP Mantle Lithosphere}

The spinel Iherzolites, spinel harzburgites, and garnet and spinel lherzolites that compose the upper OJP mantle lithosphere have dominantly coarse granular microstructures, with roughly equant grain sizes (Figures $3 \mathrm{~b}$ and $3 \mathrm{f}$ ). Exceptions are the shallow and the deepmost samples from this interval. The shallowmost spinel Iherzolite SAS64 has a medium-grained porphyroclastic microstructure. It is characterized by rare 

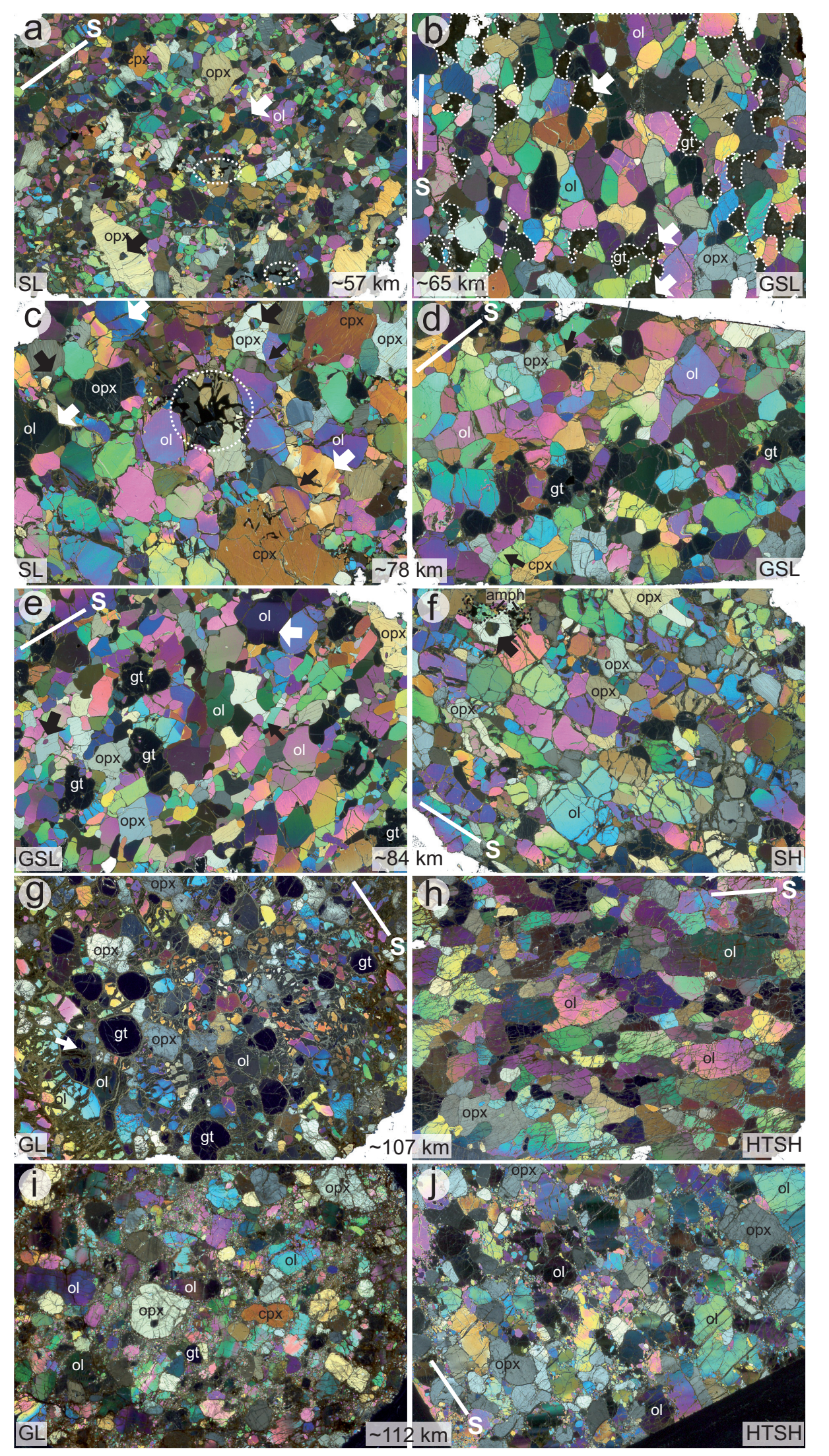
olivine and more common orthopyroxene porphyroclasts (up to $3 \mathrm{~mm}$ wide) surrounded by a matrix composed of polygonal olivine (750 $\mu \mathrm{m}$ on average) and irregularly shaped pyroxenes (Figure 3a). The deepest sample from this interval, the amphibole-bearing garnet harzburgite SAS82, has two particular features. First, the presence of garnet, which is exceptional in the otherwise garnet-barren 85-100 km depth interval. Second, it is composed by very coarse olivine crystals with strong undulose extinction and common subgrains, which are largely replaced by large poikilitic orthopyroxenes and garnet with very irregular shapes (Figure 4a) and by amphibole-spinel-clinopyroxene aggregates.

In coarse-grained spinel lherzolites, spinel harzburgites, and garnet and spinel lherzolites, olivine grains are on average $>1 \mathrm{~mm}$ wide and the coarsest grains are $>5 \mathrm{~mm}$ wide (Figure 5a). They are slightly flattened (mean apparent aspect ratios between 1.5:1 and 2:1, with maximum values at 7:1) and often display a shape-preferred orientation (SPO), which marks the foliation (Figures 3a, 3b, 3e, and 3f). The density of intracrystalline deformation features in olivine is on average low, but varies from sample to sample. In some samples, olivine shows undulose extinction and closely spaced subgrain boundaries, which are dominantly normal to the crystals elongation (white arrows in Figure 3c). In other samples, olivine displays rare, but well-defined (i.e., thin and with strong misorientations) subgrain boundaries (Figures $3 \mathrm{~b}, 3 \mathrm{~d}$, and $3 \mathrm{e}$ ). This decrease in density of intracrystalline deformation features is accompanied by a change in grain boundary morphology from curved or slightly sutured to straight (compare Figures $3 c$ and $3 b, 3 d$, and 3e). Subautomorphic olivine crystals with well-developed [010] crystal faces are locally observed. Preferred orientation of these subautomorphic olivine crystals results in a tabular microstructure in some samples (Figure 3e).

We interpret the coupled decrease in the density of intracrystalline deformation features and in the grain boundary length as marking increasing degrees of static recrystallization (annealing) of the peridotites. This evolution may be assessed by the decrease in the intracrystalline misorientation, using indicators like the average of the second-order Kernel average misorientation (mean KAM2) over all grains (Figure 5b). The garnet and spinel Iherzolites, which equilibrated between 65 and $85 \mathrm{~km}$ depth, have dominantly microstructures with a tabular tendency, characterized by rare and widely spaced subgrain walls in olivine (Figures $3 \mathrm{~b}$ and $3 \mathrm{~d}$ ). These samples have mean KAM2 values below $0.65^{\circ}$ (Figure $5 \mathrm{~b}$ ). The spinel harzburgites equilibrated between 80 and $91 \mathrm{~km}$ depth also show predominantly annealed olivines; they have mean KAM2 values between 0.58 and $0.85^{\circ}$ (Figure 5b). In contrast, the coarse granular spinel lherzolites equilibrated between 70 and $80 \mathrm{~km}$ depth display variable annealing degrees, which are not correlated to their equilibration temperatures $\left(900-1000^{\circ} \mathrm{C}\right.$, Table 1$)$. Closely spaced subgrain walls are common and grain boundaries tend to be sutured in SAS42 and SAS43 (Figure 3c), which have mean KAM2 values above $1^{\circ}$ (Figure $5 b)$. In contrast, SAS31 and SAS13 show polygonal olivine grains with rare subgrains. They have mean KAM2 values below $0.7^{\circ}$ (Figure 5b). SAS29 and SAS67 show intermediate densities of intracrystalline deformation features, to which are associated mean KAM2 values of 0.75 and $0.85^{\circ}$ (Figure $5 \mathrm{~b}$ ).

Orthopyroxenes (enstatite with Mg\# = 0.89-0.93) [Ishikawa et al., 2004] are on average 1-2 mm wide. The coarser crystals are up to $5 \mathrm{~mm}$ wide. Clinopyroxenes (diopside with Mg\# $=0.90-0.95$ ) [lshikawa et al., 2004] have variable sizes (from $<1 \mathrm{~mm}$ to $>4 \mathrm{~mm}$ ). Both orthopyroxene and clinopyroxene have very irregular

\footnotetext{
Figure 3. Photomicrographs (plane polarized light, full thin sections) showing the characteristic microstructures of the peridotites with increasing depth. (a) Porphyroclastic spinel harzburgite (SH) SAS64 showing olivine and pyroxene porphyroclasts surrounded by a matrix of fine-grained polygonal olivine and pyroxene crystals; note the subgrains in the olivine porphyroclasts (white arrows), the irregular shapes and olivine inclusions (black arrow) in orthopyroxene porphyroclasts and spinel-pyroxene symplectites (dashed white circles). (b) Garnet and spinel Iherzolite (GSL) SAS12 with a coarse granular to tabular microstructure; note the irregular shape of garnet (underlined by the white dashed line) and the rarity of intracrystalline deformation features in olivine. (c) Coarse granular spinel Iherzolite SAS43 showing common subgrains in olivine (white arrows), cusp-shaped grain boundaries and olivine inclusions in orthopyroxene (thin and thick black arrows, respectively), and large spinel-pyroxene symplectites (dashed white circle). (d) Coarse granular garnet and spinel lherzolite SAS44. (e) Tabular garnet and spinel lherzolite SAG31 displaying cusp-shaped grain boundaries and olivine inclusions in orthopyroxene (black arrows) and rare subgrains in olivine (white arrows). (f) Coarse granular spinel harzburgite with a clear olivine shape-preferred orientation (SPO) and a large proportion of curved olivine-olivine grain boundaries, as well as undulose extinction in olivine. (g) Garnet lherzolite (GL) SAG30 displaying round garnets molded by large elongated olivine grains with strong undulose extinction (white arrow); brown material along grain boundaries and fractures results from reaction with the alnöite magma. (h) Coarse granular high-temperature spinel harzburgite (HTSH) SAS69 showing a weak olivine SPO; note the stronger undulose extinction and more sutured grain boundaries in olivine relative to the shallower samples. (i) Partially recrystallized garnet lherzolite SAG27 displaying large deformed olivine and pyroxene porphyroclasts surrounded by a fine-grained olivine-rich matrix. (j) Partially recrystallized high-temperature spinel harzburgite SAS1 showing small polygonal olivine crystals developed along grain boundaries or within strongly deformed olivine porphyroclasts with very irregular shapes; note that the recrystallized grains are significantly coarser than in SAG27. The white line labeled S marks the trace of the foliation defined by the olivine SPO on the thin section plane.
} 

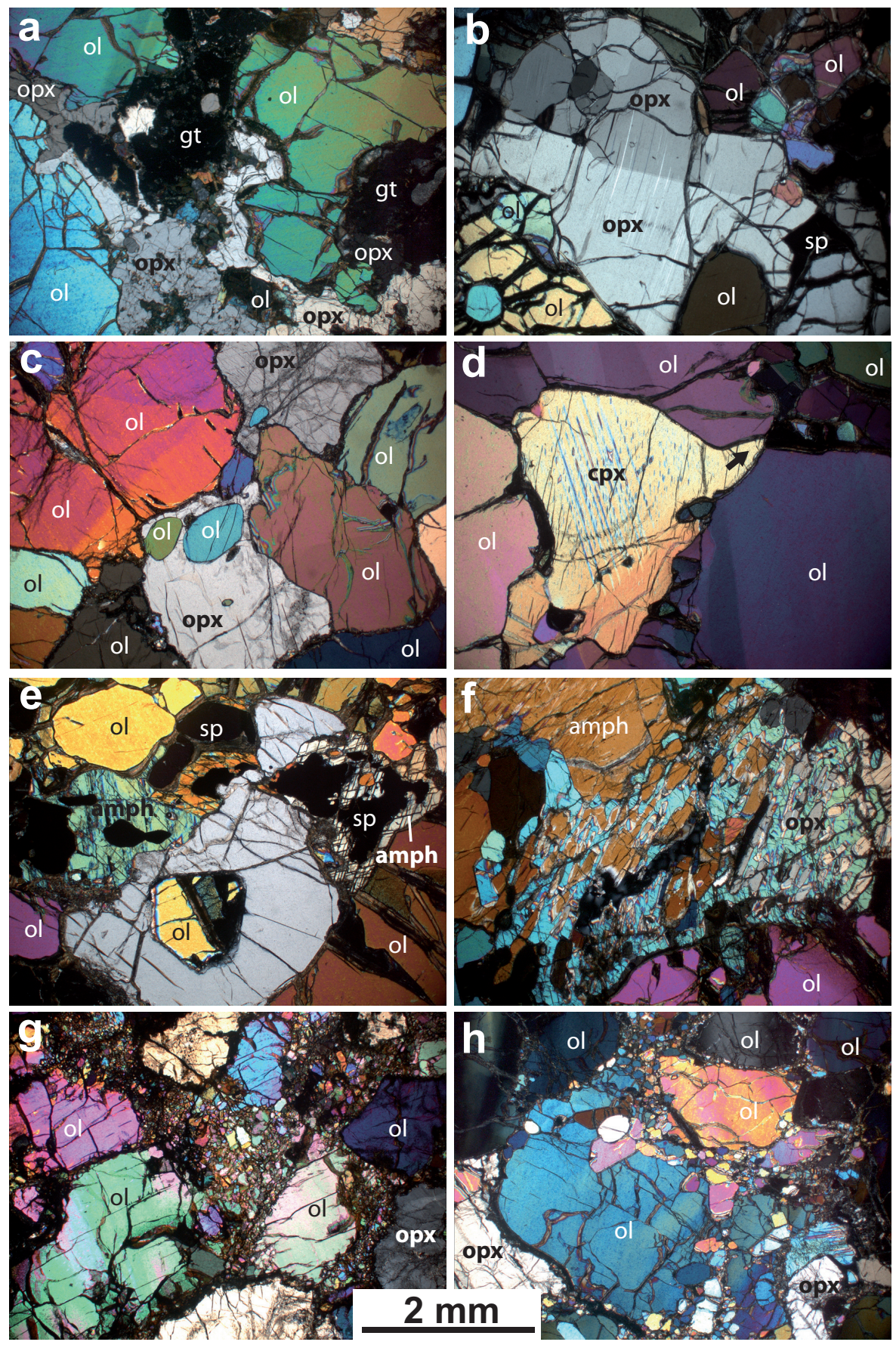

Figure 4. Photomicrographs (plane polarized light) illustrating details of the microstructure. (a) Secondary poikilitic orthopyroxenes replacing olivine in garnet harzburgite SAS82. (b) Orthopyroxene in spinel Iherzolite SAS35 showing exsolutions, kinks, and subgrains. (c) Orthopyroxene in spinel harzburgite SAS2 displaying rounded olivine inclusions; note the absence of exsolutions. (d) Clinopyroxene in spinel Iherzolite SAS43 showing exsolutions and cusp-shaped grain boundaries with olivine. (e) Irregularly shaped orthopyroxene enclosing an olivine crystal and secondary spinel-amphibole aggregates in spinel harzburgite SAS20. (f) Amphibole replacing orthopyroxene in spinel Iherzolite SAS67. (g) Fine-grained recrystallized matrix surrounding and partially replacing coarse olivine crystals in garnet lherzolite SAG27. (h) Recrystallized crystals with polygonal shapes growing over coarse deformed olivine crystals in high-temperature harzburgite SAS1.

shapes, characterized by concave contacts with olivine, often forming cusp-like terminations (thin arrows in Figures 3c, 3d, 3e, and 4d). Orthopyroxene and, more rarely clinopyroxene, contain rounded olivine inclusions, which may be actual inclusions or result from sectioning effects, denoting interpenetrating grains (black arrows in Figures 3a, 3c, 3e, 3f, and Figures 4b, 4c, and 4e). Kinks, undulose extinction, and eventually 


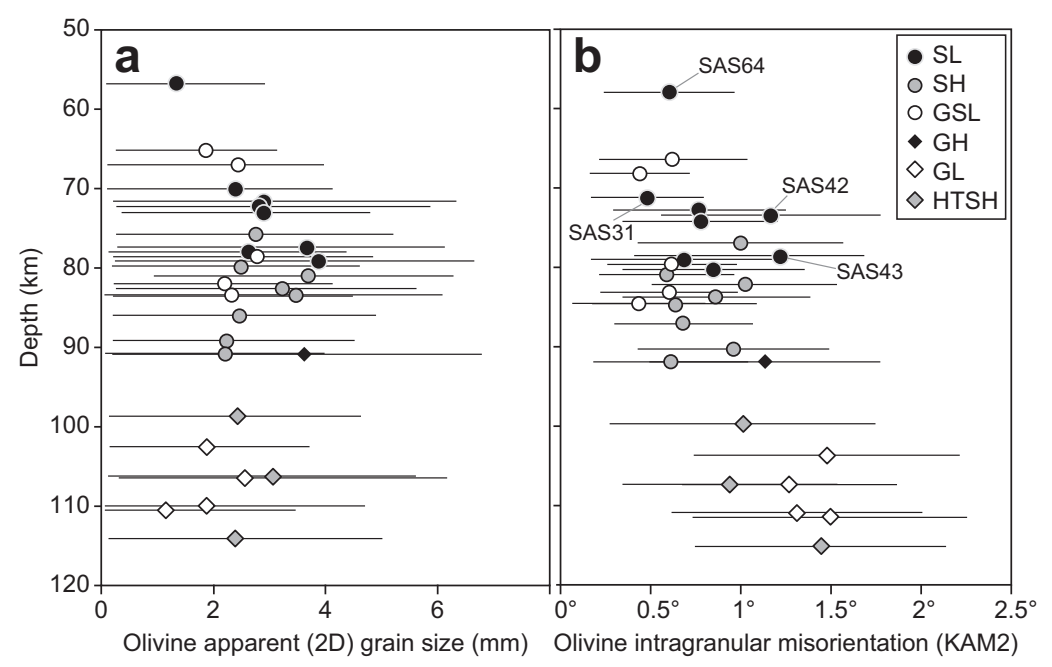

Figure 5. Olivine (a) apparent (2-D) grain sizes, represented by the diameter of a circle of similar area, and (b) intracrystalline misorientations, quantified by the mean second-order Kernel Average Misorientation (KAM2) averaged over all olivine grains in the sample, as a function of the equilibration depth. In (a) the bars indicate the apparent grain size range and the symbol, the area-ponderated mean grain size. In (b) the bars indicate the standard deviation. See methods section for definition of the second-order Kernel Average Misorientation.

subgrains are observed in orthopyroxene (Figure 4b). Diopside may show undulose extinction. The spinel Iherzolites are characterized by orthopyroxene with more sutured grain boundaries and by ubiquitous exsolutions in both orthopyroxene and clinopyroxene (Figures 3a, 3c, 4b, and 4d). Except for the shallowest spinel harzburgite SAS14, equilibrated at $972^{\circ} \mathrm{C}$, pyroxenes in spinel harzburgites and in garnet and spinel Iherzolites do not show exsolutions (Figures $3 b-3 d$ and $4 c$ ). They also have less sutured grain boundaries, but the latter still form cusps along olivine-olivine grain boundaries.

Spinel displays highly variable morphologies. In spinel Iherzolites SAS42 and SAS43, spinel forms mm size symplectites with orthopyroxene and clinopyroxene (Figure 3c). In the remaining spinel lherzolites, spinel occurs as isolated $\mathrm{mm}$ crystals with very irregular shapes, which contain common olivine and orthopyroxene rounded inclusions (Figure 3a). In the spinel harzburgites, amphiboles often surround spinel (Figure 4e). In the garnet and spinel Iherzolites, spinel usually occurs as rounded crystals within garnet (Figures $3 \mathrm{~b}$ and 3e). Garnet is almost fully transformed to kelyphite, but preserves its original irregular shape (Figures $3 b, 3 d$, and $3 e$ ). In addition to the spinel cores, it often contains olivine and orthopyroxene inclusions (Figures $3 \mathrm{~b}$, $3 d$, and $3 e)$.

Amphibole (pargasite) [Ishikawa et al., 2004] essentially occurs as irregularly shaped aggregates with spinel cores (Figure 4e). Spinel Iherzolite SAS67, which has an exceptionally high amphibole fraction (14.8\%), displays large poikilitic amphiboles, which partially replace orthopyroxene and clinopyroxenes, forming irregularly shaped pockets up to $1 \mathrm{~cm}$ wide (Figure $4 \mathrm{f}$ ).

\subsection{Lower (>100 km Depth) OJP Mantle Lithosphere}

The deeper garnet lherzolites and high-temperature harzburgites, which equilibrated at depths $>100 \mathrm{~km}$, also display coarse granular microstructures (Figures 3g-3h). They contain, however, common intracrystalline deformation features in olivine, like marked undulose extinction and closely spaced subgrain walls. This results in mean KAM2 values between 0.9 and $1.3^{\circ}$ (Figure $5 \mathrm{~b}$ ). Olivine crystals are usually elongated (aspect ratios up to 5:1) and locally seem to mold around garnet crystals (Figure 3g). Orthopyroxenes and clinopyroxenes in the high-temperature spinel harzburgites are similar to those in the shallower garnet and spinel Iherzolites. They have irregular shapes and rounded olivine inclusions (Figure 3h). A characteristic feature of the deep garnet lherzolites is the rounded shape of garnet (Figures $3 g$ and 3i). This clearly distinguishes them from the shallower garnet and spinel lherzolites, in which garnet has very irregular shapes (Figures $3 b, 3 d$, and 3e).

The three deepest peridotites (two garnet lherzolites and one high-temperature harzburgite) have a distinct microstructure. They are characterized by a bimodal grain size distribution, where a fine-grained matrix rims and sometimes overgrows the coarse grains (Figures $3 \mathbf{i}, 3 \mathbf{j}$, and $4 \mathbf{j}-4 \mathrm{~h}$ ). The coarse grains tend to be 
elongated and show marked undulose extinctions and closely spaced subgrain walls (Figures $3 \mathrm{i}$ and $3 \mathrm{j}$ ). The degree of recrystallization and the average recrystallized grain size vary between samples. Spinel harzburgite SAS1 and garnet lherzolite SAG21 display low volume fractions of recrystallized olivine crystals with polygonal shapes and sizes ranging from 150 to $500 \mu \mathrm{m}$. The recrystallized crystals have well-developed polygonal shapes and are free of intracrystalline deformation features. They occur either along the boundaries of the deformed olivine porphyroclasts or overgrow them (Figures 3j and 4h). Garnet lherzolite SAG27 shows a higher volume fraction of recrystallized olivine crystals with finer grain sizes (25-100 $\mu \mathrm{m})$, which surround most olivine porphyroclasts and crosscut, partially disaggregating, some crystals (Figures $3 \mathrm{i}$ and $4 \mathrm{~g}$ ). These three peridotites are characterized by the highest mean KAM2 values of the entire suite $\left(>1.4^{\circ}\right.$, Figure $5 \mathrm{~b}$ ).

\subsection{Pyroxenites}

Shallow pyroxenites, which equilibrated dominantly at pressures $<2.7 \mathrm{GPa}$, are dominantly garnet websterites and spinel-garnet clinopyroxenites with metamorphic (exsolution-dominated, in response to cooling) microstructures. Their primary mineralogy, deduced from the exsolution and reaction textures, changes from garnet websterites to spinel-garnet clinopyroxenites as follows: clinopyroxene $\rightarrow$ clinopyroxene + orthopyroxene $\rightarrow$ clinopyroxene + orthopyroxene + spinel $\rightarrow$ clinopyroxene + spinel + garnet. These mineral assemblages suggest that they represent cumulates crystallized along lithospheric conduits [Ishikawa et al., 2004].

Deep pyroxenites, which were equilibrated at pressures $>3 \mathrm{GPa}$, are mainly garnet-clinopyroxenites or garnet-orthopyroxenites with cumulate-type coarse-grained textures. They are characterized by absence of spinel and of exsolution textures. The petrochemical variations observed in these deep pyroxenites have been attributed to reactions between basaltic melts and peridotitic material [Ishikawa et al., 2004, 2007].

The studied pyroxenites display no evidence for solid-state deformation. An exception is garnet pyroxenite SAE141, which equilibrated at $>110 \mathrm{~km}$ depth. It shows, like the deepest peridotites, a bimodal grain size distribution, where a fine-grained pyroxene-rich matrix surrounds pyroxenes and garnet porphyroclasts. Quartz-bearing garnet clinopyroxenite SAE116, equilibrated at $\sim 116 \mathrm{~km}$ depth, is also particular. It contains small irregularly shaped quartz aggregates along garnet-clinopyroxene contacts [cf. Ishikawa et al., 2004, Figure 3f], which may have formed from coesite.

\section{Crystal Preferred Orientations}

\subsection{Olivine}

Olivine has crystal preferred orientations (CPO) with variable intensities (J-indexes = 3.2-11.5; Table 1). Some of the highest values may, however, represent an overestimation of the actual CPO strength as $<100$ crystals could be measured in some thin sections, due to the coarse grain sizes and large proportion of pyroxenes in some specimens. The olivine CPO strength does not vary systematically with depth, though the three shallowest peridotites have weak olivine CPO (Figure 6a). High-temperature spinel harzburgites and the garnet harzburgite SAS82 tend to show strong olivine CPO and garnet and spinel lherzolites display dominantly weak olivine CPO. Other lithologies show, however, variable olivine CPO strength.

CPO symmetries are also variable, ranging from [100]-fiber to [010]-fiber (BA-indexes ranging from 0.1 to 0.9 ), with a predominance of [010]-fiber and orthorhombic patterns (BA indexes $<0.65$, Figure $6 \mathrm{~b}$ and Table 1). These different olivine CPO symmetries are illustrated in Figure 7, which displays the CPO of olivine, orthopyroxene and clinopyroxene of selected samples representative of the different equilibration conditions and lithological types observed among the Malaita peridotite xenoliths. CPO data for all samples is presented in supporting information Figure S3.

Orthorhombic olivine CPO is characterized by three orthogonal point concentrations of [100], [010], and [001], with stronger concentrations of the [100] and [010] axes (cf. samples SAS64, SAG27, SAG30, and SAS1 in Figure 7). [010]-fiber (or axial-[010]) olivine CPO is characterized by a point concentration of [010] and girdles of [100] and [001] with weak maxima at $90^{\circ}$ to each other. The [100] maximum is always stronger than the [001] one (cf. samples SAS31, SAS29, SAG31, and SAS20 in Figure 7). [100]-fiber (or axial-[100]) olivine CPO, only displayed by spinel harzburgite SAS59 (Figure 7), is characterized by a strong point concentration of [100] and by girdles of [010] and [001] normal to it.

There is no clear relation between lithological type and the symmetry of the olivine CPO (Figure 6b). However, among the deeper samples, garnet lherzolites tend to have [010]-fiber olivine CPO, whereas high- 


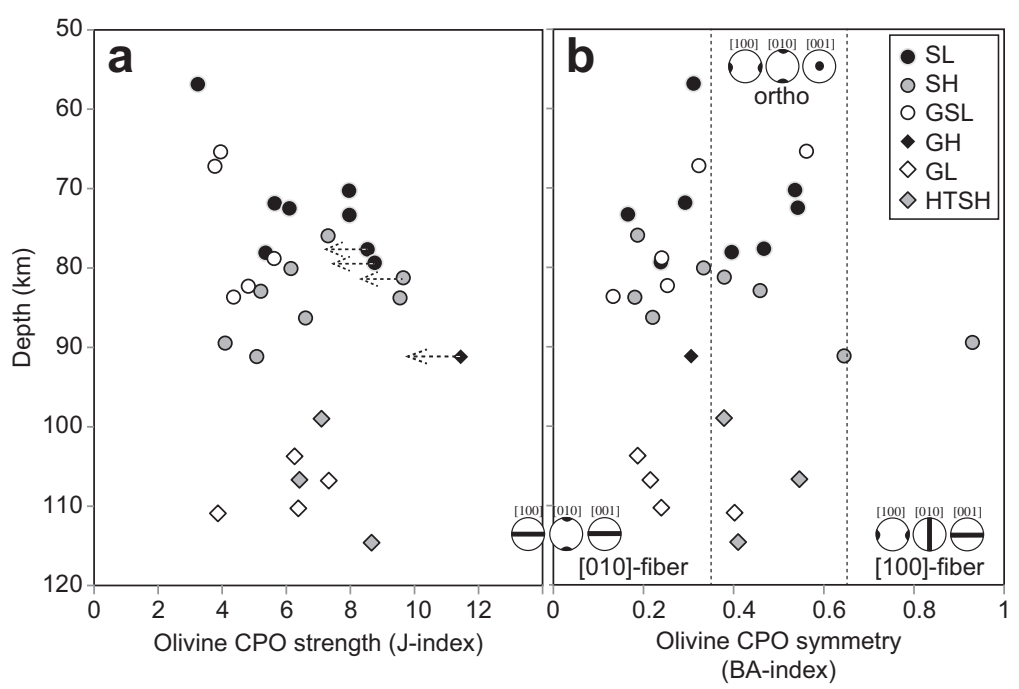

Figure 6. Olivine crystal preferred orientation strength (quantified by J-index) and symmetry (quantified by the BA-index) as a function of the equilibration depth. See methods section for the definition of these two indexes. Dashed arrows indicate samples for which the CPO strength might have been overestimated, due to measurement of $<100$ olivine grains.

temperature spinel harzburgites have more orthorhombic olivine CPO. The highest variability in olivine CPO symmetry is displayed by the spinel harzburgites.

There is, in contrast, some relation between olivine CPO symmetry and microstructure. Samples with tabular textures tend to show [010]-fiber olivine CPO (BA index <0.35) (Table 1). The reciprocal is not true, as peridotites bearing [010]-fiber olivine CPO may have either coarse granular or tabular textures (Table 1). The [010] concentration is, however, always perpendicular to the foliation defined by olivine elongation (Figure 7).

\subsection{Orthopyroxene and Clinopyroxene}

Analysis of the pyroxenes CPO was hindered in many samples by the small number of grains present in the thin section, which results in poor definition of the CPO (multiple maxima in the pole figures, Figure 7 and supporting information S3) and does not allow for the quantification of the CPO strength. Orthopyroxene and clinopyroxene CPO are, however, well correlated in most samples, as indicated by the parallelism of their [001] maximum (Figure 7). [100] and [010] axes of both pyroxenes tend to be more dispersed and to have more variable orientation than the [001] axis.

Comparison of the pyroxene and olivine CPO allows discriminating between samples where the olivine [100] maximum is parallel to the pyroxenes [001] maximum ("correlated" CPO, implying that the dominant slip directions of the three minerals are aligned, most probably marking the past flow direction) and samples where the maximum concentration of pyroxenes [001] axes does not coincide with the olivine [100] axis maximum ("uncorrelated" CPO). Garnet lherzolites and high-temperature spinel harzburgites display well-defined pyroxene CPO, which are correlated to the olivine CPO (Figure 7 and supporting information S3). In addition to a clear [001] maximum for both pyroxenes parallel to the olivine [100] one, pyroxenes in these high-temperature peridotites show an alignment of either [100] or [010] parallel to the olivine [010] maximum, that is, normal to the foliation, or girdles of these two axes normal to the [001] maximum, that is, normal to the lineation. Garnet and spinel Iherzolites also show correlated pyroxenes and olivine CPO (Figure 7 and supporting information S3).

The correlation between the pyroxenes and olivine CPOs is less clear in the shallower levels of the OJP mantle lithosphere. Spinel Iherzolites show weak pyroxenes CPO, which are in most cases poorly correlated to the olivine CPO (Figure 7 and supporting information S3). Half of the studied spinel harzburgites show orthopyroxene CPO correlated with the olivine CPO. The other half show uncorrelated orthopyroxene CPO, often characterized by an orthopyroxene [001] maximum subparallel to the olivine [001] maximum (cf. sample SAS20 in Figure 7). The amount of clinopyroxene in the spinel harzburgites is too low for a statistical 

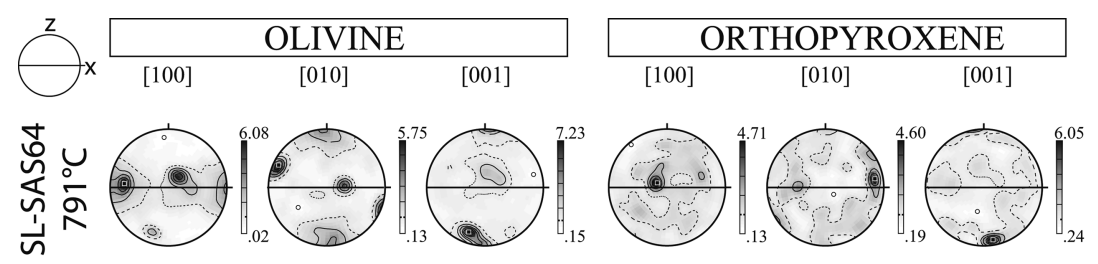

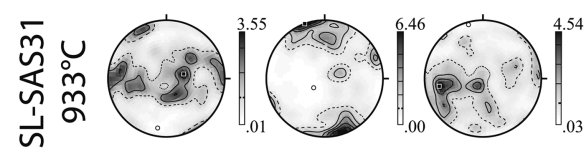
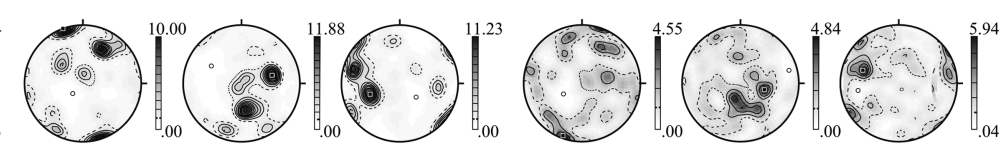

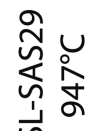
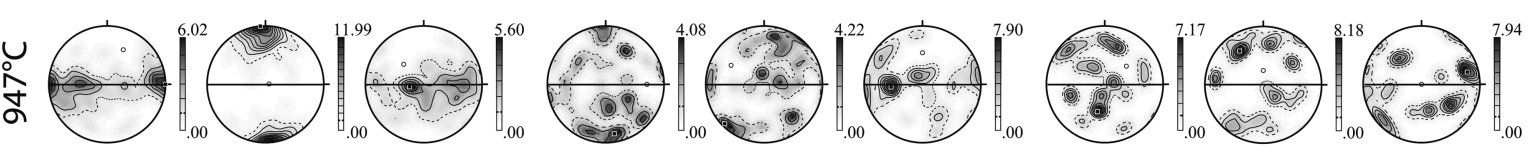

热
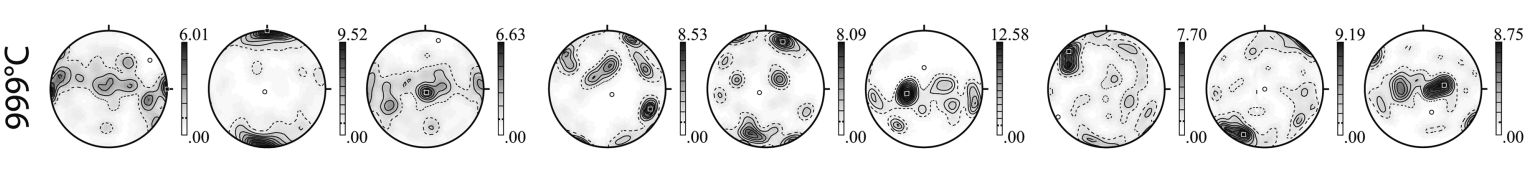

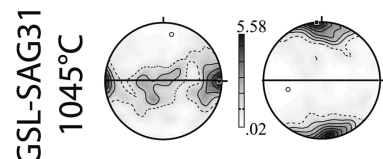
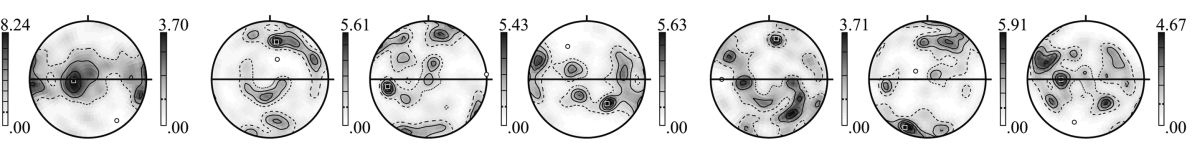

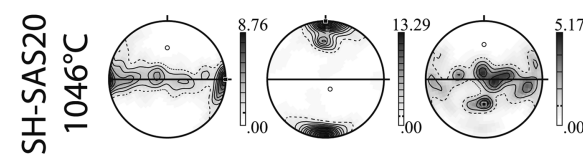
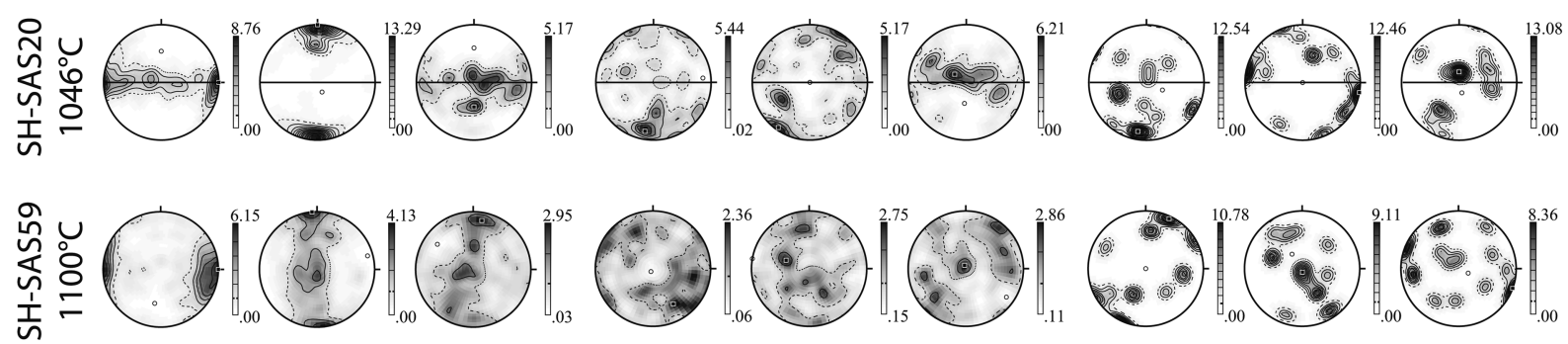

ชิ

芒

$\stackrel{1}{\mathfrak{N}}$

王

잉

岁
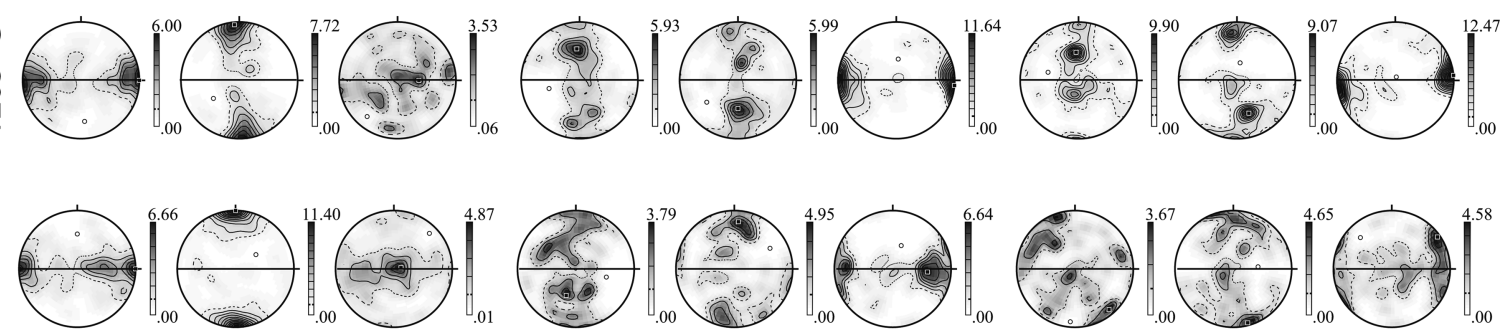

जิ
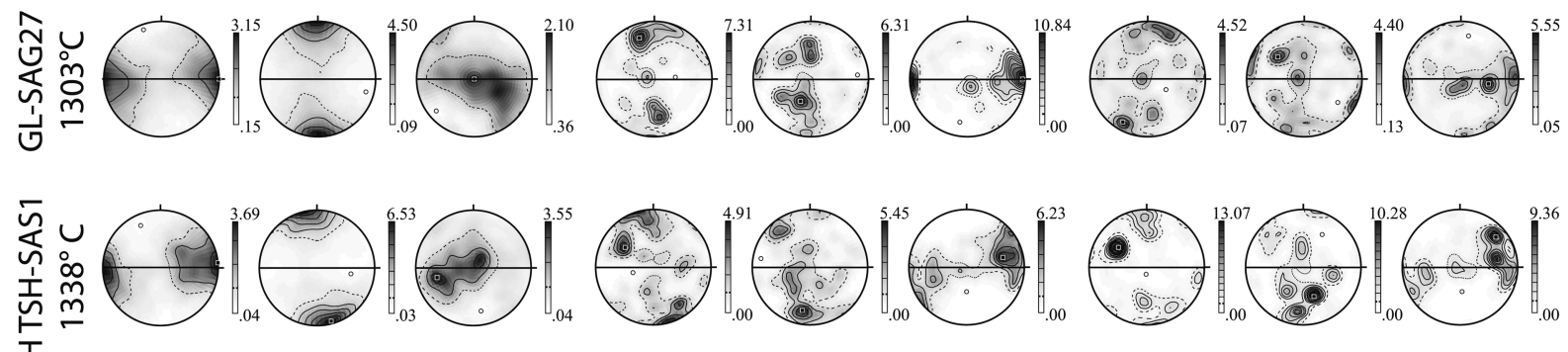

Figure 7. Crystallographic preferred orientation (CPO) of olivine, orthopyroxene, and clinopyroxene in selected samples representative of the different equilibration conditions and lithological types observed among the Malaita mantle xenoliths. Lower hemisphere equal area stereographic projections, contours at multiples of uniform distribution. Horizontal line marks the foliation plane in those samples displaying an olivine shape-preferred orientation (top left insert displays the structural reference frame, where $\mathrm{x}$ marks the lineation and $\mathrm{z}$ the normal to the foliation). 


\section{QAGU Geochemistry, Geophysics, Geosystems}
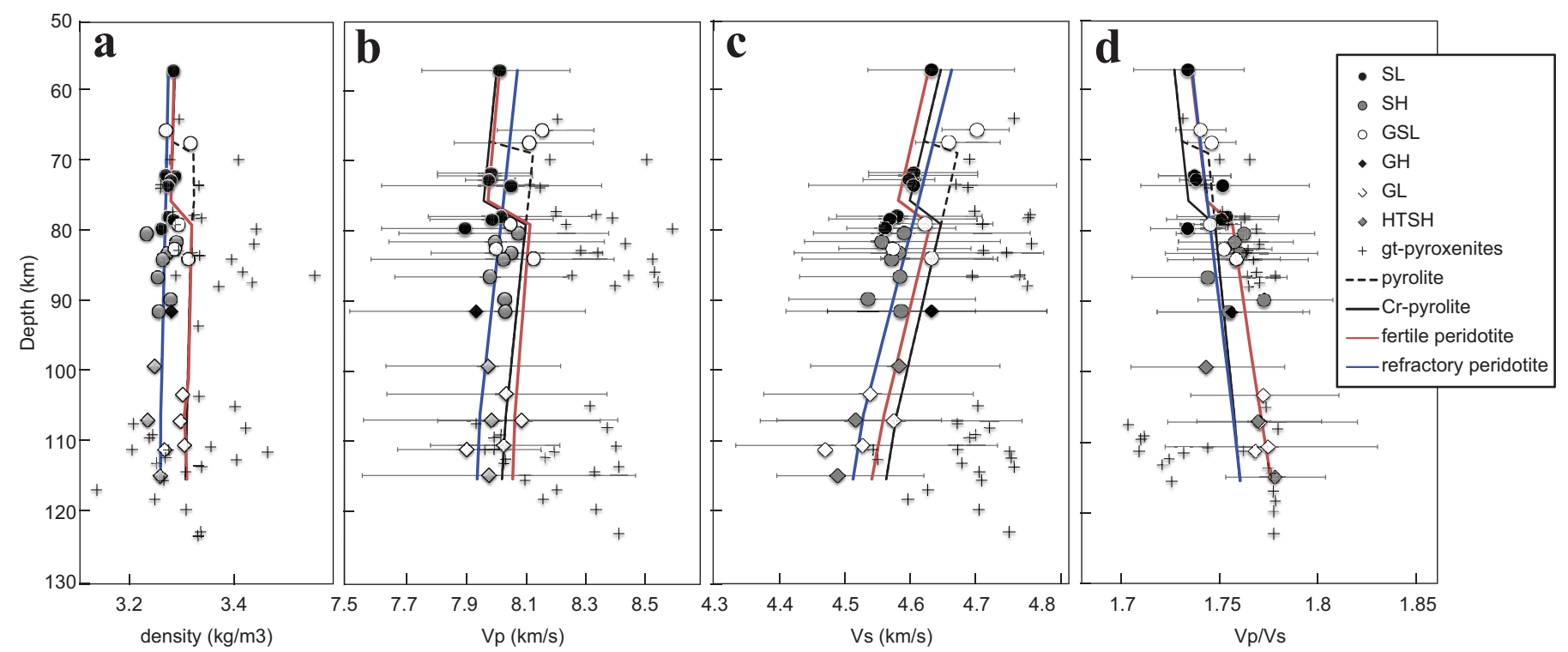

Figure 8. Variation of seismic velocities with equilibration depth. (a) Density. (b) Mean ( isotropic) $P$ wave velocity, bars indicate the maximum and minimum $P$ wave velocity, that is,

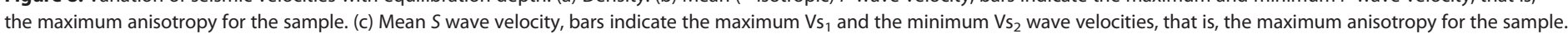

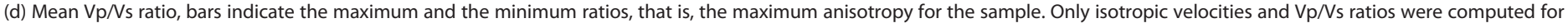
the pyroxenites. The modal compositions for the reference fertile and refractory mantle models are shown in supporting information Figure S1.

characterization of the CPO, but in many samples there is no clear relation between the clinopyroxene CPO and the olivine one (Figure 7 and supporting information S3).

\section{Seismic Properties}

In spite of some dispersion due to the compositional heterogeneity (Table 1), the calculated density and mean $P$ wave velocities of the peridotites decrease weakly with depth (Figures $8 \mathrm{a}$ and $8 \mathrm{~b}$ ). Calculated $S$ waves velocities show a more marked decrease with depth (Figure 8c), indicating a higher sensitivity to temperature. This results in increase in the $\mathrm{Vp} / \mathrm{Vs}$ ratio with depth (Figure $8 \mathrm{~d}$ ). Since both $P$ and $S$ waves increase with increasing garnet content, garnet-bearing lherzolites tend to show higher velocities than spinel harzburgites at a given depth (Figures $8 \mathrm{~b}$ and $8 \mathrm{c}$ ). This variation is less marked for $P$ wave velocities, which are also very sensitive to the orthopyroxene content. For instance, garnet harzburgite SAS82, which has 32\% orthopyroxene (Table 1), shows high $S$ wave, but low $P$ wave velocities.

The higher modal content of garnet (Table 2) results in higher densities and seismic velocities for the pyroxenites relative to the peridotites at a given depth (Figure 8). As for the peridotites, high orthopyroxene contents lower the density and the $P$ and $S$ wave velocities in pyroxenites. This effect is more marked for the density and $P$ wave velocity, accounting for densities and $P$ waves velocities in some pyroxenites equivalent to those in the peridotites (Figures $8 \mathrm{a}$ and $8 \mathrm{~b}$ ). It also explains the low $\mathrm{Vp} / \mathrm{Vs}$ ratios displayed by the deep pyroxenites (Figure $8 \mathrm{~d}$ ), which often have very high orthopyroxene contents ( $>60 \%$, Table 2 ).

The calculated densities and seismic velocities of the Ontong Java peridotites are, in general, bounded by the density and seismic velocity profiles calculated for "typical" refractory and fertile peridotite compositions using the geotherm defined based on the equilibration temperatures and pressures of the xenoliths (Figure $1 \mathrm{~b}$; the modal composition as a function of depth for these models is shown in supporting information Figure S1). Some harzburgites show, however, lower densities than those predicted for a "typical" refractory peridotite due to their high orthopyroxene contents (Table 1). Lower garnet contents than those predicted for a "typical" fertile peridotite (12-13\%) might account for the rather low seismic velocities and densities of some Iherzolites, which are more consistent with refractory compositions. Finally, the high amphibole content of spinel Iherzolite SAS67 (15\%, Table 1) and garnet harzburgite SAS82 (9\%) might explain their low $P$ wave velocities relatively to the ones predicted for "typical" fertile peridotites equilibrated at the same conditions. 


\section{QAGU Geochemistry, Geophysics, Geosystems}
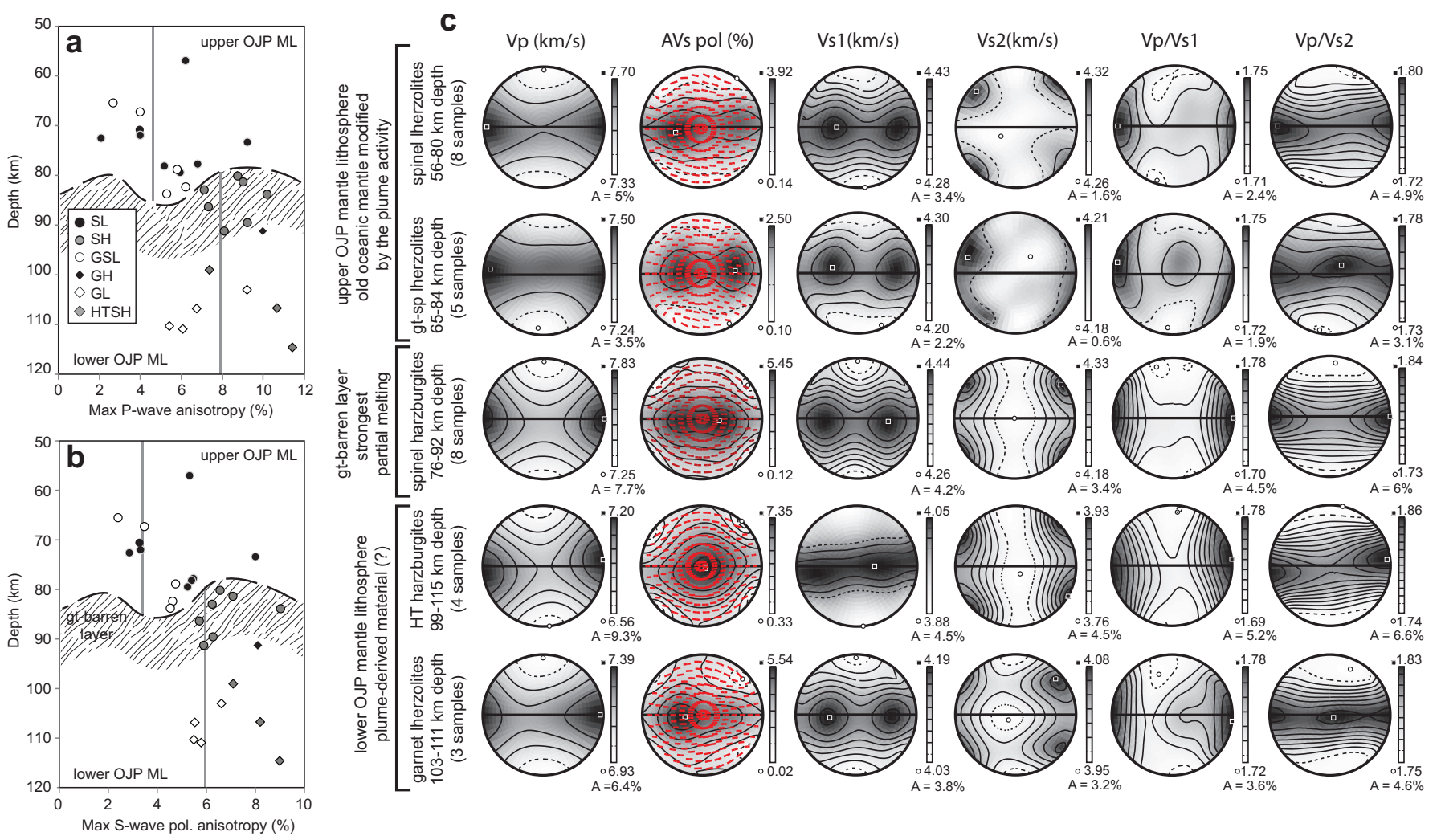

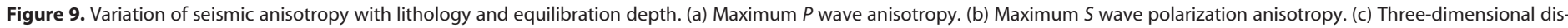

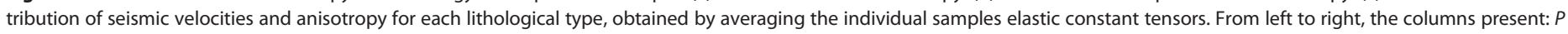
wave velocity, contours at $0.1 \mathrm{~km} / \mathrm{s}$ intervals. $S$ wave polarization anisotropy, contours at $1 \%$ intervals. $S_{1}$ wave velocity, contours at $0.02 \mathrm{~km} / \mathrm{s}$ intervals. $S_{2}$ wave velocity, contours at

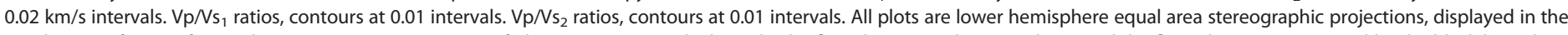
peridotites reference frame: the maximum concentration of olivine [100] axes, which marks the flow direction is horizontal E-W and the flow plane is represented by the black line. The gray bars in Figures 9a and 9b indicate the average anisotropy in the upper and lower OJP mantle lithosphere; for calculating these averages the spinel harzburgites were included in the lower OJP mantle lithosphere. The limits of the garnet-barren layer are represented as wavy surfaces to recall that they are probably not planes but convoluted surfaces, similar to the melt percolation front mapped in the Lherz peridotite massif in the French Pyrenees [Le Roux et al., 2008].

Seismic anisotropy for both $P$ and $S$ waves varies strongly from sample to sample, due to variations in the olivine modal content and in the olivine CPO strength and symmetry. Maximum $P$ wave anisotropy ranges from 2 to $11.5 \%$ and maximum $S$ wave anisotropy ranges from 2.4 to $9 \%$ (Figures $9 \mathrm{a}$ and $9 \mathrm{~b}$ and Table 1). Late crystallization of amphibole only slightly decreases the anisotropy (compare $P$ and $S$ wave anisotropy for samples SAS76 with 15\% of pargasite and SAS44 that has no pargasite in Table 1). In spite of the large dispersion, the deeper part of the section (below $\sim 85 \mathrm{~km}$ depth) tends to show higher anisotropy. This increase in anisotropy is largely due to the larger proportion of harzburgites, which display stronger anisotropies for both $P$ and $S$ waves (Figures $9 a$ and $9 b$ ).

The seismic anisotropy patterns for average samples for each lithology (calculated by averaging the individual samples elastic constant tensors) are rather homogeneous (Figure 9c) and correspond to those most commonly observed in naturally deformed mantle peridotites [Ben Ismail and Mainprice, 1998; Mainprice, 2007; Tommasi et al., 2000]. $P$ waves are fastest when propagating parallel to the maximum concentration of olivine [100] axes. Both $P$ and the fast $S$ wave $\left(S_{1}\right)$ are slowest when traveling parallel to the maximum concentration of [010] axes (perpendicular to the foliation, when the latter is observed). The fast shear wave $S_{1}$ is always polarized parallel to the olivine [100] maximum and the maximum birefringence is generally observed for shear waves propagating at high angle $\left(>60^{\circ}\right)$ to the [100] maximum in the foliation plane. Love and Rayleigh wave velocities also vary significantly depending of the orientation of the olivine CPO frozen in the OJP mantle lithosphere. The fast $S$ wave $\left(S_{1}\right)$ propagates faster within the foliation plane; it is the fastest at $45^{\circ}$ to olivine [100] axes maximum. The slow $S$ wave $\left(S_{2}\right)$ is slow for all propagation directions normal to the olivine [100] maximum; it is the fastest at $45^{\circ}$ to both the [100] and [010] maxima. Maximum 
propagation anisotropies are generally lower for $S$ waves than for $P$ waves. The peridotites' intrinsic anisotropy also results in a directional dependence of the $\mathrm{Vp} / \mathrm{Vs}$ ratios. The highest $\mathrm{Vp} / \mathrm{Vs}_{1}$ ratios (1.75-1.78) are measured for waves propagating parallel to the maximum concentration of olivine [100] axes, that is, parallel to the flow direction, and the lowest (1.69-1.72), for waves propagating parallel to the maximum concentration of olivine [010] axes, that is, normal to the flow plane.

The change in olivine CPO symmetry with increasing depth results in a variation in the $S$ wave polarization anisotropy pattern (Figure 9c). In upper part of the OJP mantle lithosphere, where [010]-fiber olivine CPO predominate ( $\sim 68 \%$, Figure $6 \mathrm{~b})$, the anisotropy for waves propagating parallel to the [010] maximum, that is, at high angle to the flow plane, is $<1 \%$ (Figure 9c). This implies that such waves would sample almost no anisotropy. In contrast, in the deeper part of the OJP mantle lithosphere, where the proportion of [010]-fiber olivine CPO decreases ( $57 \%$, Figure $6 \mathrm{~b}$ ), waves propagating normal to the flow plane will sample anisotropies of $2-3 \%$ (Figure 9c). The variation of the olivine CPO symmetry also changes slightly the $P$ and $S$ waves propagation anisotropy patterns, but these variations are of second order (Figure 9c).

\section{Discussion}

7.1. Microstructures and Crystal Preferred Orientations: Constraints on Deformation Processes, Annealing, and Metasomatism in the OJP Mantle Lithosphere

The well-developed olivine and, for most samples, pyroxene CPO (Figure 7 and supporting information Figure S3) together with the preserved intracrystalline deformation features, like undulose extinction, subgrains, and kinks, indicate that the studied peridotites have been deformed by dislocation creep. Olivine CPO have either an orthorhombic symmetry consistent with dominant activation of the [100](010) slip system or a fiber-[010] symmetry (55\% of the samples). Orthorhombic olivine CPO is usually produced in simple shear [Hansen et al., 2014; Tommasi et al., 2000; Zhang and Karato, 1995]. [010]-fiber olivine CPO may result from (1) transpressional deformation [Tommasi et al., 1999], (2) simultaneous activation of [100] and [001] glide due to high pressure, stresses, or water contents in olivine [Demouchy et al., 2013; Durham and Goetze, 1977; Jung et al., 2006; Mainprice et al., 2005], (3) deformation in presence of melt [Higgie and Tommasi, 2012, 2014], or (4) recrystallization [Falus et al., 2011; Tommasi et al., 2008]. Hypothesis (1) cannot explain the data. Water contents measured in olivine from these peridotites (2-32 ppm wt $\mathrm{H}_{2} \mathrm{O}$ ) [Demouchy et al., 2014] are much lower than those proposed to result in significant activation of [001] glide [Jung et al., 2006]. Equilibration pressures ( $<3.5 \mathrm{GPa})$ are also too low and the coarse grain sizes imply low stresses. Transpression may explain some of the observed fiber-[010] patterns. Among the garnet and spinel lherzolites, many samples show a dispersion of the orthopyroxene and clinopyroxene [001] axes in the foliation plane, similar to the one displayed by the olivine [100] axes (Figure 7 and supporting information Figure S3). This observation is consistent with a CPO symmetry controlled by the deformation regime. It favors therefore a transpressional origin for the [010]-fiber olivine CPO. However, other samples show point concentrations of the pyroxene [001] axes. Hypotheses (3) and (4) cannot therefore be discarded for explaining some of the observed fiber-[010] olivine CPO.

With exception of those samples equilibrated the shallowest (SAS64) and deepest depths (SAG21, SAG27, and SAS1) that are porphyroclastic, the OJP peridotites have coarse granular to tabular microstructures (Figure 3). In addition, the garnet and spinel lherzolites, most spinel harzburgites, and some of the spinel Iherzolites that compose the upper OJP mantle lithosphere have low intracrystalline misorientations (Figure 5b) and a high proportion of straight olivine-olivine grain boundaries (Figures 3b, 3d, and 3e). We interpret these features as the result of postdeformation annealing (static recrystallization). This annealing differentiates these peridotites from those derived from other domains of the Pacific mantle lithosphere affected by a less strong plume activity. For instance, peridotite xenoliths from Tahiti and Tubuai, in French Polynesia show dominantly coarse to medium-grained porphyroclastic microstructures [Tommasi et al., 2004]. The sole specimen in the present study that shows microstructures similar to those observed in French Polynesia xenoliths is the shallowest spinel Iherzolite SAS64 (Figure 3a).

In contrast, the garnet lherzolites and high-temperature harzburgites that compose the lower OJP mantle lithosphere show low annealing degrees (Figures $3 g-3 j$ and $5 b$ ) in spite of their high equilibration temperatures. This suggests that deformation continued until their extraction. The coarse grain sizes ( $>1 \mathrm{~mm}$, Figures $3 \mathrm{~g}$ and $3 \mathrm{~h}$ ) imply low stresses [Van der Wal et al., 1993], consistent with those predicted for the 
convective mantle ( 1 MPa) [Turcotte and Schubert, 2014]. Asthenospheric deformation cannot, however, account for the fine-grained recrystallized microstructures of the deepest peridotites (Figures $3 \mathrm{i}$ and $3 \mathrm{j}$ ) and pyroxenites, which imply in stresses on the order of $100 \mathrm{MPa}$ [Van der Wal et al., 1993]. At the equilibration temperatures of these peridotites, such stresses are associated with strain rates $>10^{-8} \mathrm{~s}^{-1}$ [Hirth and Kohlstedt, 2003], which are many orders of magnitude higher than those produced by the relative displacement between the plates and the convective mantle $\left(10^{-14}\right.$ to $\left.10^{-15} \mathrm{~s}^{-1}\right)$. We propose therefore that the recrystallized microstructures are associated with the initiation of the dykes that fed the alnöitic volcanism. This interpretation is similar to the one proposed to explain the mylonitic textures in kimberlite peridotite xenoliths [Green and Gueguen, 1974; Baptiste et al., 2012]. Textural and compositional modification shortly before extraction is corroborated by the disequilibrium profiles, especially in garnet, displayed by these recrystallized samples (supporting information Figure S5).

Quenched microstructures, as those observed in the deep OJP mantle lithosphere, may allow identifying deformation events that occurred shortly before extraction of the peridotites from the mantle. There are, however, no tools for dating the deformation or the annealing in the upper OJP mantle lithosphere. Yet, considering the geodynamic context of OJP, we hypothesize that the annealing may have resulted from heating of the mantle lithosphere due to the plume activity.

Interaction with percolating melts or fluids (metasomatism) in the mantle lithosphere atop the plume may favor annealing by allowing for enhanced diffusion along wetted grain boundaries. Spinel lherzolites, in particular, show variable annealing degrees, which do not correlate with the equilibration temperatures (Figure $5 b)$. They also show variable enrichment in rare-earth elements, which denote variable degrees of metasomatism (Figure 2). Interestingly, the two observations are qualitatively correlated. The shallowest spinel Iherzolite (SAS64), which has a porphyroclastic texture, shows very depleted REE patterns. The weakly annealed samples SAS42 and SAS43 also show depleted patterns. In contrast, the strongly annealed spinel lherzolites SAS13 and SAS31 show enrichment in LREE, indicative of metasomatism. SAS35 is less metasomatized and shows limited annealing (mean KAM2 of $0.77^{\circ}$ ). For SAS29, the correlation is less clear; it displays limited annealing (mean KAM2 of $0.78^{\circ}$ ), but enriched REE patterns. SAS67 is a particular case; it is equilibrated at rather high temperature $\left(>1000^{\circ} \mathrm{C}\right.$, Table 1$)$ and shows strongly enriched REE patterns, consistent with its high amphibole content, but has olivine with undulose extinction and common subgrains.

Enrichment in REE is not the sole evidence for reactional transport of melts and fluids through the OJP mantle lithosphere. Reactive melt percolation is corroborated by the large proportion of pyroxenites among the xenoliths carried by the Malaita alnöite [Ishikawa et al., 2004]. Ages of crystallization could not be determined, but based on their primary basaltic compositions and on the lack of solid-state deformation, we hypothesize that the pyroxenites represent the products of melt percolation under static conditions in the mantle lithosphere atop the plume wake. An exception is the deep garnet pyroxenite SAE141, which, similarly to the peridotites equilibrated at depths $>110 \mathrm{~km}$, is partially recrystallized to a fine-grained matrix, indicating high stress deformation shortly before its extraction.

In addition, diffuse reactive percolation of melts leading to crystallization of orthopyroxenes at the expenses of olivine in the peridotites is evidenced by (1) high modal contents of orthopyroxene $(>25 \%)$ in many OJP peridotites, (2) the irregular shapes of the pyroxenes, in particular, the cusp-like terminations at pyroxeneolivine-olivine contacts, and their frequent olivine inclusions (Figures 3 and 4), and (3) the lack of consistence between the olivine and pyroxene CPO (that is, the nonparallelism between the maximum concentrations of the main glide directions of olivine and orthopyroxene, which are [001] and [100], respectively; Figure 7 and supporting information Figure S3). All peridotites that show orthopyroxene CPO not consistent with the olivine CPO have high orthopyroxene contents ( $>20 \%$ and reaching up to $36 \%$, Table 1 ), suggesting postkinematic addition of pyroxene. However, some spinel lherzolites and spinel-harburgites show orthopyroxene enrichment, but consistent olivine and orthopyroxene CPO. This may be explained by prekinematic or synkinematic reactive percolation (suggesting multiple percolation episodes in the shallow OJP mantle). It may, however, also result from postkinematic topotaxial growth of the secondary orthopyroxenes onto primary deformed orthopyroxenes. High orthopyroxene contents (31 or 42\%, Table 1) are also observed in some garnet lherzolites and high-temperature spinel harzburgites. The pyroxenes CPO in these peridotites are nevertheless consistent with the olivine CPO (Figure 7). Based on the CPOs correlation and on the lower degree of annealing of these peridotites (Figure $5 \mathrm{~b}$ ), we propose that reactive melt percolation in the deep OJP mantle is prekinematic or synkinematic. 
Finally, the occurrence of undeformed amphibole-spinel aggregates and the petrographic evidence for replacement of pyroxenes by amphibole (Figures $3 e$ and $3 f$ ) indicate modal metasomatism by hydrous melts. This metasomatism is clearly postkinematic. In garnet harzburgite SAS82, it results in crystallization of orthopyroxene and garnet at the expenses of olivine, strong enrichment in Fe in olivine (Table 1), and chemical disequilibrium in orthopyroxene and garnet (supporting information Figure S5). The latter characteristic indicates that, in this sample, metasomatism by hydrous melts shortly predated the extraction by the alnöite magma and might be related to it. This temporal relation cannot, however, be extended to all amphibole-bearing peridotites.

\subsection{Densities and Seismic Velocities}

Density and seismic velocity profiles constructed based on the modal compositions and equilibration temperatures and, for the peridotites, CPO and olivine forsterite contents are coherent with the evolution of density and seismic velocities for normal mantle compositions along a cold oceanic geotherm (Figure 8). Calculated densities decrease very slightly with depth. They depend strongly on the composition. The garnet-barren interval between 85 and $105 \mathrm{~km}$ depth displays on average lower densities. On the other hand, enrichment of the OJP mantle in pyroxenites between 70 and $85 \mathrm{~km}$ and below $105 \mathrm{~km}$ depth, which is suggested by the abundance of pyroxenites among the Malaita xenoliths, might result in local density increase. Irregular distribution of high-density garnet-pyroxenites within the OJP mantle lithosphere might indeed account for the low coherence between the Bouguer gravity and the bathymetry spectra at intermediate wavelengths (250-500 km), which was proposed by lto and Taira [2000] to result from magmatic underplating. Moreover, if the abundance of pyroxenites is the record of a large proportion of eclogitic material in OJP plume, the associated density increase in the plume might reconcile the limited uplift of the plateau [Roberge et al., 2005] with a hot plume origin.

Calculated $P$ wave velocities decrease slightly with depth (Figure $8 b$ ). $S$ wave velocities show a more marked decrease (Figure $8 c$ ), indicating stronger temperature dependence. This results in a marked increase in the $\mathrm{Vp} / \mathrm{Vs}$ ratio with depth (Figure $8 \mathrm{~d}$ ). Because of the strong compositional heterogeneity observed at all depths, the stratification of the OJP mantle (Figure 1c) does not result in sharp variation in seismic velocities, which could give rise to intralithospheric reflectors. Reflectors may, however, be produced by a change in the orientation of the deformation structures and, hence, of the seismic anisotropy (cf. discussion in section 7.3). Enrichment of the OJP mantle between 70 and $85 \mathrm{~km}$ and below $105 \mathrm{~km}$ depth in garnet-bearing pyroxenites, suggested by the abundance of such lithologies among the Malaita xenoliths, might result in local increase in $P$ and $S$ wave velocities (Figures $8 \mathrm{~b}$ and $8 \mathrm{c}$ ). It might also, if orthopyroxene contents are high, locally decrease the Vp/Vs ratios (Figure $8 \mathrm{~d}$ ).

Even without large amounts of garnet-bearing pyroxenites in the OJP mantle, $S$ wave velocities calculated using the OJP peridotites' data (Figure 8c) are significantly higher than the Rayleigh wave velocities obtained by Richardson et al. [2000], which range with increasing depth from 4.5 to $3.9 \mathrm{~km} / \mathrm{s}$. They are also higher than those derived from the analysis of multiple ScS phases, which show delays of 2.5-3s for a path between the Solomon Islands and Pohnpei with bounce points within the plateau [Gomer and Okal, 2003]. Possible explanations for this discrepancy are (1) the low-velocity anomaly imaged seismologically beneath the OJP results from smearing from low velocities actually located south of the OJP, in the Solomon-New Hebrides subarc region, (2) it is restricted to the sublithospheric mantle ( $>120 \mathrm{~km}$ ) beneath OJP, (3) it developed after the xenoliths' extraction (at $34 \mathrm{Ma}$ ) in response to subduction of the Australian plate under the OJP, (4) the studied xenoliths are not fully representative of the OJP mantle lithosphere, or (5) small melt fractions are present in the mantle beneath OJP. Concerning the hypothesis (4), although the sampling site is located at the southwestern border of the OJP, the studied xenolith suite records a compositional and age layering that is fully consistent with modification and partial replacement of an old oceanic lithosphere by an impacting plume [Ishikawa et al., 2004, 2005, 2007, 2011]. We presume therefore that they are representative of the OJP mantle root. The xenoliths do not allow testing hypothesis (5), since they only sample the solid mantle. Based on the analysis of the megacrysts carried by the alnöitic volcanism, Ishikawa et al. [2004] proposed, however, that small fractions of highly evolved melts might have survived for long times within the OJP mantle root, with the alnöite eruption representing some of these melts. The slow Rayleigh waves velocities imaged by Richardson et al. [2000] might be explained by 1-2\% melt within flat pockets (aspect ratios $\gg 10: 10: 1$ ) oriented either subhorizontally or vertically in the E-W direction, that is, normal to the Rayleigh wave polarization or to the dominant propagation direction in the tomographic model 
[Mainprice, 1997, 2007; Vauchez et al., 2000; Tommasi et al., 2006; Kawakatsu et al., 2009]. However, there is no isotropic or anisotropic melt distribution [Mainprice, 2007] compatible with the association of low attenuation (high $\mathrm{Q}$ values) and low seismic velocities inferred from the analysis of ScS waves reverberating beneath the OJP. Thus, if the low attenuation is confirmed, it rules out the existence of even very small melt fractions in the upper mantle beneath OJP.

\subsection{Seismic Anisotropy}

The shallow OJP mantle lithosphere is significantly less anisotropic than the lower mantle lithosphere (Figure 9), because it contains a higher proportion of Iherzolites (lower content in olivine) and because the olivine CPO in the garnet spinel Iherzolites and in the shallow spinel Iherzolites is mainly weak (Figure 6a). This change in intensity of anisotropy (Figure 9) is the sole variation in seismic properties that marks the compositional stratification of the OJP mantle lithosphere (Figure 1c). As discussed below, this contrast will be stronger if the orientation of the deformation structures (foliation and lineation) in the upper and lower OJP mantle lithosphere differs.

[010]-Fiber olivine CPO, which predominates among the OJP peridotites, results in very low isotropy for waves propagating normal to the foliation (Figure 9c). Thus, if the frozen structures in the upper OJP mantle lithosphere record mainly horizontal shearing due to a velocity gradient between the plate and the convecting mantle [e.g., Tommasi, 1998], this layer will contribute very little to teleseismic shear wave splitting. Surface waves will be characterized by SH faster than SV, but will show weak azimuthal anisotropy (cf. azimuthal anisotropy for $S$ waves propagating in the foliation plane in Figure 9c).

Vertical lineations, which might have formed in the lower mantle lithosphere in response to small-scale convection in the plume wake [e.g., Agrusta et al., 2013], will produce limited teleseismic shear wave splitting ( $\mathrm{dt} \sim 0.2 \mathrm{~s}$, considering that the thickness of this layer is ca. $35 \mathrm{~km}$, Figure 9c). Vertical lineations in the lower OJP mantle lithosphere will result in SV faster than $\mathrm{SH}$, with significant Rayleigh waves azimuthal anisotropy ( 3.7\%) within this layer (Figure 9c). Moreover, if lineations and foliations frozen in the lower OJP lithosphere are vertical, the change in orientation of the foliation relative to the upper mantle lithosphere, where horizontal foliations are expected [Tommasi, 1998], will produce a significant velocity contrast for vertically propagating $P$ waves (an increase of ca. 7\%; Figure 9c). This anisotropy-induced contrast in seismic properties may produce an intralithospheric reflector. The reflectivity for an incidence normal to this interface is low (0.03). It increases, however, for incidence angles around $30^{\circ}$ and higher than $60^{\circ}$ [Auger, 1994]. Significant signal is also expected for SP conversions at incidence angles around $10^{\circ}$ and for PS conversions at incidence angles between 25 and $60^{\circ}$ [Auger, 1994].

No shear wave splitting data are presently available for seismic stations within the OJP. The SKS splitting data [Klosko et al., 2001] is restricted to the OJP periphery; it samples the mantle anisotropy around and not beneath the plateau. Stations KOS, NAU, and PNI show fast polarizations subparallel to the Pacific absolute plate motion, which is the expected pattern in an oceanic plate far from plate boundaries [Fontaine et al., 2007; Tommasi, 1998]. Delay times range between 0.6s at KOS and 1.1s at NAU and PNI. These values are slightly lower than the average ones in southern Pacific [Fontaine et al., 2007]. They are consistent therefore with a weak seismic anisotropy of the shallow mantle lithosphere, as the one inferred for the shallow OJP mantle lithosphere if the foliation is horizontal (Figure 9c). Station TKK, which is located at the northwestern extremity of OJP, show different fast polarization directions for waves with western and eastern backazimuths: $\mathrm{N}$ and $\mathrm{NE}$, respectively. This suggests either anisotropy with a dipping symmetry axis or variations (vertical or lateral) of the anisotropy. However, xenoliths' data cannot be used to discriminate between these interpretations, because the orientation of the olivine CPO in the geographic reference frame was lost during extraction.

\section{Conclusion}

The study of the microstructures and crystal preferred orientations (CPO) of a xenolith-based section sampling the mantle root of the Ontong Java Plateau (OJP) from 60 to $120 \mathrm{~km}$ depth shows that coarse granular microstructures with roughly equant grains predominate. Porphyroclastic microstructures are only observed in the peridotites equilibrated at the shallowest $(>70 \mathrm{~km})$ and deepest $(>110 \mathrm{~km})$ depths. Intracrystalline deformation features in olivine and pyroxenes and the well-developed olivine CPO suggest deformation by 
dislocation creep, with dominant activation of the [100](010) slip system. Transpression, deformation in presence of melt, or a change in the olivine CPO during recrystallization has to be invoked, however, to explain the large proportion of olivine CPO with a fiber-[010] symmetry.

The compositional stratification with depth of the OJP mantle lithosphere is accompanied by a variation in the annealing degree, which has been approximated by the quantification of the mean intracrystalline misorientation. The spinel Iherzolites, spinel harzburgites and garnet and spinel Iherzolites that compose the upper OJP mantle lithosphere ( $<100 \mathrm{~km}$ depth) are variably annealed. In contrast, the garnet lherzolites and high-temperature spinel harzburgites that compose the lower OJP mantle lithosphere show no evidence for effective annealing.

The peridotites that compose the OJP mantle lithosphere also often display textural evidence for reactive percolation of melts. This evidence includes (1) the irregular shapes of pyroxenes, which form cusps along olivine-olivine contacts and contain common olivine inclusions, (2) inconsistent olivine and pyroxenes CPO, and (3) presence of undeformed amphibole. Reactive transport of melts and fluids through the OJP mantle is further suggested by enrichment in pyroxenes in many peridotites and by the abundance of pyroxenites among the xenoliths. Although dating of such processes is impossible, considering the OJP geodynamic setting, we hypothesize that the both the annealing and the metasomatism in the upper OJP mantle lithosphere result from the plume activity.

Density and seismic velocity profiles calculated based on the modal compositions and equilibration temperatures and, for the peridotites, CPO and olivine forsterite contents show a weak decrease of density and mean $P$ wave velocities with depth. Calculated $S$ waves show a more marked decrease, resulting in increase in the $\mathrm{Vp} / \mathrm{Vs}$ ratio with depth. Due to the strong compositional heterogeneity at all depths, the stratification of the OJP mantle root does not produce sharp contrasts in seismic velocities. The peridotites' seismic properties are consistent with normal mantle compositions and a cold oceanic geotherm beneath OJP. Enrichment in garnet-bearing pyroxenites in the OJP mantle lithosphere might locally further increase densities and seismic velocities. The calculated seismic properties are therefore not consistent with the low $S$ waves velocities predicted by Rayleigh wave tomography models [Richardson et al., 2000] and ScS data [Gomer and Okal, 2003].

Seismic anisotropy of the peridotite xenoliths is variable (2-12\%). The lithospheric section below ca. $80 \mathrm{~km}$ (that is, the plume accreted material and the high refractory layer that marks the interface between this material and the preexisting oceanic lithosphere) has on average higher anisotropy (up to $8 \%$ for $P$ waves and $6 \%$ for $S$ waves polarization anisotropy). Seismic anisotropy data for the OJP mantle, which would allow constraining the orientation of the foliation and lineation in the OJP mantle root is lacking. We may, how-

Acknowledgments

The data supporting the conclusions of this article are presented in the text or in the online supporting information. This collaborative research was funded by the Ministère des Affaires Etrangères in France and the Japan Society for the Promotion of Science under the JapanFrance Integrated Action Program (PHC SAKURA) $759445 C$. We thank M. Shimojo for help with the acquisition of EBSD data, D. Mainprice for providing softwares for calculating seismic properties and macros for analyzing CPO with the MTEX toolbox, and J.A. Padron-Navarta for calculating fertile and depleted mantle modal compositions changes along the Ontong Java geotherm. L. Hansen and two anonymous reviewers are thanked for thoughtful reviews. C. Nevado and D. Delmas supplied high quality polished thin sections for EBSD measurements. F. Barou helped with EBSD data acquisition. The EBSD-SEM facility at the University of Montpellier 2 is supported by the CNRS-INSU and Conseil Régional Languedoc-Roussillon (France). ever, predict, based on the calculated seismic anisotropy, that if foliations are horizontal, vertically propagating $S$ waves and Rayleigh waves will sample very weak anisotropy in the upper OJP mantle. In addition, if the lineations in the deep mantle lithosphere are vertical, the change in orientation of the olivine CPO may give rise to an intralithospheric reflector.

\section{References}

Abramson, E. H., M. Brown, L. J. Slutsky, and J. Zaug (1997), The elastic constants of San Carlos olivine up to 17 GPa, J. Geophys. Res., 102, 12,252-212,263.

Agrusta, R., D. Arcay, A. Tommasi, A. Davaille, N. Ribe and T. Gerya (2013), Small-scale convection in a plume-fed low viscosity layer beneath a moving plate, Geophys. J. Int., 194, 591-610, doi:10.1093/gji/ggt128.

Anders, E., and N. Grevesse (1989), Abundances of the elements: Meteoritic and solar, Geochim. Cosmochim. Acta, 53, $197-214$.

Auger, E. (1994) Etude de la reflection des ondes sismiques à l'interface entre deux milieux anisotropes, Diplôme d'Etudes Approfondis, 26 pp., Univ. de Montpellier 2, Montpellier, France.

Bachmann, F., R. Hielscher, P. E. Jupp, W. Pantleon, H. Schaeben, and E. Wegert (2010), Inferential statistics of electron backscatter diffraction data from within individual crystalline grains, J. Appl. Crystallogr., 43(6), 1338-1355, doi:10.1107/S002188981003027X.

Bachmann, F., R. Hielcher, and H. Schaeben (2011), Grain detection from 2d and 3d EBSD data-Specification of the MTEX algorithm, Ultramicroscopy, 11, 1720-1733.

Baptiste, V., A. Tommasi, and S. Demouchy (2012), Deformation and hydration of the lithospheric mantle beneath the Kaapval craton, Lithos, 149, 31-50, doi:10.1016/j.lithos.2012.05.001.

Ben Ismail, W., and D. Mainprice (1998), An olivine fabric database: An overview of upper mantle fabrics and seismic anisotropy, Tectonophysics, 296, 145-158.

Bezacier, M. L. (2012), Propriétés élastiques des minéraux hydratés: Applications à l'anisotropie sismique dans les zones de subduction, PhD thesis, 199 pp., Ecole Normale Supérieure. de Lyon, Univ. de Lyon, Lyon, France.

Bianco, T. A., G. Ito, J. van Hunen, M. D. Ballmer, and J. J. Mahoney (2008), Geochemical variation at the Hawaiian hot spot caused by upper mantle dynamics and melting of a heterogeneous plume, Geochem. Geophys. Geosyst., 9, Q11003, doi:10.1029/2008GC002111. 
Brey, G. P., and T. Köhler, (1990), Geothermobarometry in four-phase Iherzolites. II: New thermobarometers, and practical assessment of existing thermobarometers, J. Petrol., 31, 1353-1378.

Bunge, H. J. (1982), Texture Analysis in Materials Sciences, 593 pp., Buttleworth, London, U. K.

Chai, M., J. M. Brown, and L. J. Slutsky (1997a), The elastic constants of a pyrope-grossular-almandine garnet up to 20 GPa, Geophys. Res. Lett., 24(5), 523-526.

Chai, M., J. M. Brown, and L. J. Slutsky (1997b), The elastic constants of an aluminous orthopyroxene to 12.5 GPa, J. Geophys. Res., 102, 14,779-14,786, doi:10.1029/97JB00893.

Collins, M. D., and J. M. Brown (1998), Elasticity of an upper mantle clinopyroxene, Phys. Chem. Miner., 26, 7-13.

Demouchy, S., A. Tommasi, T. Boffa Ballaran, and P. Cordier (2013), Low strength of Earth's uppermost mantle inferred from tri-axial deformation experiments on dry olivine crystals, Phys. Earth Planet. Inter., 220, 37-49.

Demouchy, S., A. Ishikawa, A. Tommasi, O. Alard, and S. Keshav (2014), Hydration of olivine in the mantle lithosphere: Peridotite xenoliths from the Ontong Java Plateau as an example. Lithos, doi: 10.1016/j.lithos.2014.11.005.

Durham, W. B., and C. Goetze (1977), Plastic flow of oriented single crystals of olivine. 1: Mechanical data, J. Geophys. Res., 82, 57375753.

Falus, G., A. Tommasi, and V. Soustelle (2011), The effect of dynamic recrystallization on olivine crystal preferred orientations in mantle xenoliths deformed under varied stress conditions, J. Struct. Geol., 33, 1528-1540.

Fitton, J. G., and M. Godard (2004), Origin and evolution of magmas on the Ontong Java Plateau, in Origin and Evolution of the Ontong Java Plateau, edited by J. G. Fitton et al., pp. 151-178, Geol. Soc., London, U. K.

Fontaine, F., G. Barruol, A. Tommasi and G. Bokelmann (2007), Upper mantle flow beneath French Polynesia from shear-wave splitting, Geophys. J. Int., 170, 1262-1288, doi:10.1111/j.1365-246X.2007.03475.x.

Gomer, B. M., and E. A. Okal (2003), Multiple-ScS probing of the Ontong-Java Plateau, Phys. Earth Planet. Inter., 138, $317-331$.

Green, H. W., and Y. Gueguen (1974), Origin of kimberlite pipes bu diapiric upwelling in the upper mantle, Nature, 249, 617-620.

Hansen, L. N., Y. H. Zhao, M. E. Zimmerman, and D. L. Kohlstedt (2014), Protracted fabric evolution in olivine: Implications for the relationship among strain, crystallographic fabric, and seismic anisotropy, Earth Planet. Sci. Lett., 387, 157-168.

Hearmon, R. F. S. (1984), The elastic constants of crystals and other anisotropic materials, in Landolt-Bornstein Tables, edited by K. H. Hellwege and A. M. Hellwege, pp. 1-154, Springer, Berlin.

Herzberg, C. T. (2004), Partial melting below the Ontong Java Plateau, in Origin and Evolution of the Ontong Java Plateau, edited by J. G. Fitton et al., pp. 179-183, Geol. Soc., London, U. K.

Hielscher, R., and H. Schaeben (2008), A novel pole figure inversion method: Specification of the MTEX algorithm, J. Appl. Crystallogr., 41, 1024-1037, doi:10.1107/S0021889808030112.

Higgie, K., and A. Tommasi (2012), Feedbacks between deformation and melt distribution in the crust-mantle transition zone of the Oman ophiolite, Earth Planet. Sci. Lett., 359, 61-72.

Higgie, K., and A. Tommasi (2014), Deformation in a partially molten mantle: Constraints from plagioclase-lherzolites from Lanzo, western Alps, Tectonophysics, 615-616, 167-181.

Hirth, G., and D. Kohlstedt (2003), Rheology of the upper mantle and the mantle wedge: A view from the experimentalists, in Inside the subduction Factory, Geophys. Monogr., vol. 138, edited by J. Eiler, pp. 83-105, AGU, Washington, D. C.

Isaak, D. G., O. L. Anderson, and H. Oda (1989), Elasticity of single-crystal forsterite measured to 1700K, J. Geophys. Res., 94, 5895-5906.

Ishikawa, A., S. Maruyama, and T. Komiya (2004), Layered lithospheric mantle beneath the Ontong Java Plateau: Implications from xenoliths in alnoüite, Malaita, Solomon Islands, J. Petrol., 45, 2011-2044.

Ishikawa, A., E. Nakamura, and J. J. Mahoney (2005), Jurassic oceanic lithosphere beneath the southern Ontong Java Plateau: Evidence from xenoliths in alnoüite, Malaita, Solomon Islands, Geology, 33, 393-396.

Ishikawa, A., T. Kuritani, A. Makishima, and E. Nakamura (2007), Ancient recycled crust beneath the Ontong Java Plateau: Isotopic evidence from the garnet clinopyroxenite xenoliths, Malaita, Solomon Islands, Earth Planet. Sci. Lett., 259, 134-148.

Ishikawa, A., D. G. Pearson, and C. W. Dale (2011), Ancient Os isotope signatures from the Ontong Java Plateau lithosphere: Tracing lithospheric accretion history, Earth Planet. Sci. Lett., 301, 159-171.

Ito, G., and A. Taira (2000), Compensation of the Ontong Java Plateau by surface and subsurface loading, J. Geophys. Res., 105, $11,171-111,183$.

Jung, H., I. Katayama, Z. Jiang, T. Hiraga, and S. I. Karato (2006), Effect of water and stress on the lattice-preferred orientation of olivine, Tectonophysics, 421, 1-22.

Kawakatsu, H., P. Kumar, Y. Takei, M. Shinohara, T. Kanazawa, E. Araki, and K. Suyehiro (2009), Seismic evidence for sharp lithosphereasthenosphere boundaries of oceanic plates, Science, 324, 499-502.

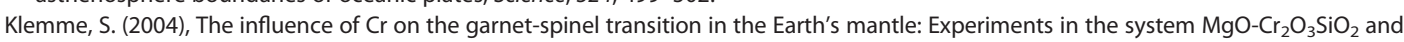
thermodynamic modelling, Lithos, 77, 639-646.

Klosko, E. R., R. M. Russo, E. A. Okal, and W. P. Richardson (2001), Evidence for a rheologically strong chemical mantle root beneath the Ontong-Java Plateau, Earth Planet. Sci. Lett., 186, 347-361.

Kumazawa, M., and O. L. Anderson (1969), Elastic moduli, pressure derivatives, and temperature derivatives of single-crystal olivine and single-crystal forsterite, J. Geophys. Res., 74, 5961-5972.

Le Roux, V., A. Tommasi and A. Vauchez (2008), Feedback between melt percolation and deformation in an exhumed lithosphereasthenosphere boundary, Earth Planet. Sci. Lett., 274, 401-413.

Mahoney, J. J., M. Storey, R. A. Duncan, K. J. Spencer, and M. Pringle (1993), Geochemistry and geochronology of Leg 130 basement lavas: Nature and origin of the Ontong Java Plateau, Proc. Ocean Drill. Program Sci. Results, 130, 3-22.

Mainprice, D. (1990), A FORTRAN program to calculate seismic anisotropy from the lattice preferred orientation of minerals, Comput. Geosci., 16(3), 385-393.

Mainprice, D. (1997) Modelling the anisotropic seismic properties of partially molten rocks found at mid-ocean ridges, Tectonophysics, 279, $161-179$.

Mainprice, D. (2007), Seismic anisotropy of the deep Earth from a mineral and rock physics perspective, in Treatise in Geophysics, edited by G. Schubert, pp. 437-491, Elsevier, Amsterdam, Netherlands.

Mainprice, D., G. Barruol, and W. Ben Ismail (2000), The seismic anisotropy of the Earth's mantle: From single crystal to polycrystal, in Earth's Deep Interior: Mineral Physics and Seismic Tomography: From Atomic to Global Scale, edited by S.-I. Karato et al., pp. 237-264, AGU, Washington, D. C.

Mainprice, D., A. Tommasi, H. Couvy, P. Cordier, and D. J. Frost (2005), Pressure sensitivity of olivine slip systems and seismic anisotropy of Earth's upper mantle, Nature, 433, 731-733. 
Mainprice, D., R. Hielscher, and H. Schaeben (2011), Calculating anisotropic physical properties from texture data using the MTEX opensource package, in Deformation Mechanisms, Rheology and Tectonics: Microstructures, Mechanics and Anisotropy, Spec. Publ., vol. 360, edited by D. Prior, E. H. Rutter, and D. Tathan, pp. 175-192, Geol. Soc., London, U. K., doi:10.1144/sp360.10.

Mainprice, D., F. Bachmann, R. Hielcher, and H. Schaeben (2014), Descriptive tools for the analysis of texture projects with large datasets using MTEX-Strength, symmetry and components, in Rock Deformation from Field, Experiments and Theory: A Volume in Honour of Ernie Rutter, Spec. Publ., edited by D. R. Faulkner, E. Mariani, and J. Mecklenburgh, 409 pp., Geol. Soc., London, U. K., doi:10.1144/SP409.8.

Mookherjee, M., and L. Bezacier (2012), The low velocity layer in subduction zone: Structure and elasticity of glaucophane at high pressures, Phys. Earth Planet. Inter., 208, 50-58.

Nimis, P., and H. Grütter (2010), Internally consistent geothermometers for garnet peridotites and pyroxenites, Contrib. Miner. Petrol., 159, 411-427.

Nixon, P. H., and F. R. Boyd (1979), Garnet bearing Iherzolites and discrete nodule suites from the Malaita alnoite, Solomon Islands, S.W. Pacific, and their bearing on oceanic mantle composition and geotherm, in The Mantle Sample: Inclusions in Kimberlite and Other Volcanics, edited by F. R. Boyd and H. O. A. Meyer, pp. 400-423, AGU, Washington, D. C.

Nickel, K. G., and D. H. Green (1985), Empirical geothermobarometry for garnet peridotites and implications for the nature of the lithosphere, kimberlites and diamonds. Earth Planet. Sci. Lett., 73, 158-170.

Nixon, P. H., and C. R. Neal (1987), Ontong Java Plateau: Deep-seated xenoliths from thick oceanic lithosphere, in Mantle Xenoliths, edited by P. H. Nixon, pp. 335-345, John Wiley, N. Y.

Reichmann, H. J., and S. D. Jacobsen (2004), High-pressure elasticity of a natural magnetite crystal, Am. Mineral., 89, $1061-1066$.

Richardson, W. P., E. A. Okal, and S. van der Lee (2000), Rayleigh-wave tomography of the Ontong-Java Plateau, Phys. Earth Planet. Inter., $118,29-51$.

Roberge, J., P. J. Wallace, R. V. White, and M. F. Coffin (2005), Anomalous uplift and subsidence of the Ontong Java Plateau inferred from $\mathrm{CO}_{2}$ contents of submarine basaltic glasses, Geology, 33, 501-504.

Suzuki, I., O. L. Anderson, and Y. Yumino (1983), Elastic properties of a single-crystal forsterite $\mathrm{Mg}_{2} \mathrm{SiO}_{4}$ up to $1200 \mathrm{~K}$, Phys. Chem. Miner., 10, 38-46.

Taylor, W. R. (1998), An experimental test of some geothermometer and geobarometer formulations for upper mantle peridotites with application to the thermobarometry of fertile Iherzolite and garnet websterite, Neues Jahrbuch für Mineralogie-Abhandlungen, $381-408$.

Tejada, M. L. G., K. Suzuki, T. Hanyu, J. J. Mahoney, A. Ishikawa, Y. Tatsumi, Q. Chang, and S. Nakai (2013), Cryptic lower crustal signature in the source of the Ontong Java Plateau revealed by Os and Hf isotopes, Earth Planet. Sci. Lett., 377-378, 84-96.

Thoraval, C., A. Tommasi, and M. P. Doin (2006), Plume-lithosphere interaction beneath a fast moving plate, Geophys. Res. Lett., 33, L01301, doi:10.1029/2005GL024047.

Tommasi, A. (1998), Forward modeling of the development of seismic anisotropy in the upper mantle, Earth Planet. Sci. Lett., 160, 1-13.

Tommasi, A., B. Tikoff, and A. Vauchez (1999), Upper mantle tectonics: Three-dimensional deformation, olivine crystallographic fabrics and seismic properties, Earth Planet. Sci. Lett., 168, 173-186.

Tommasi, A., D. Mainprice, G. Canova, and Y. Chastel (2000), Viscoplastic self-consistent and equilibrium-based modeling of olivine lattice preferred orientations: Implications for upper mantle seismic anisotropy, J. Geophys. Res., 105, 7893-7908.

Tommasi, A., M. Godard, G. Coromina, J.-M. Dautria, and H. Barsczus (2004), Seismic anisotropy and compositionally induced velocity anomalies in the lithosphere above mantle plumes: A petrological and microstructural study of mantle xenoliths from French Polynesia, Earth Planet. Sci. Lett., 227, 539-556.

Tommasi, A., A. Vauchez, M. Godard, and F. Belley (2006), Deformation and melt transport in a highly depleted peridotite massif from the Canadian Cordillera: Implications to seismic anisotropy above subduction zones, Earth Planet. Sci. Lett., 252, 245-259.

Tommasi, A., A. Vauchez, and D. A. lonov (2008), Deformation, static recrystallization, and reactive melt transport in shallow subcontinental mantle xenoliths (Tok Cenozoic volcanic field, SE Siberia), Earth Planet. Sci. Lett., 272, 65-77, doi:10.1016/j.epsl.2008.04.020.

Turcotte, D., and G. Schubert (2014), Geodynamics, 3rd ed., Cambridge Univ. Press, Cambridge, U. K.

Van der Wal, D., P. Chopra, M. Drury, and J. FitzGerald (1993), Relationships between dynamically recrystallized grain size and deformation conditions in experimentally deformed olivine rocks, Geophys. Res. Lett., 20, 1479-1482.

Vauchez, A., A. Tommasi, G. Barruol, and J. Maumus (2000), Upper mantle deformation and seismic anisotropy in continental rifts, Phys. Chem. Earth Part A, 25, 111-117.

Vollmer, F. W. (1990), An application of eigenvalue methods to structural domain analysis, Geol. Soc. Am. Bull., 102, $786-791$.

Webb, S. (1989), The elasticity of the upper mantle orthosilicates olivine and garnet to 3 GPa, Phys. Chem. Miner., 16, 684-692.

Weidner, D. J., and H. R. Carleton (1977), Elasticity of coesite, J. Geophys. Res., 82, 1334-1346.

Zhang, S., and S. Karato (1995), Lattice preferred orientation of olivine aggregates in simple shear, Nature, 375, $774-777$. 